\title{
Last glacial ice sheet dynamics offshore NE Greenland - a case study from Store Koldewey Trough
}

\author{
Ingrid Leirvik Olsen ${ }^{1}$, Tom Arne Rydningen ${ }^{1}$, Matthias Forwick ${ }^{1}$, Jan Sverre Laberg ${ }^{1}$, and Katrine Husum ${ }^{2}$ \\ ${ }^{1}$ Department of Geosciences, UiT The Arctic University of Norway, Box 6050 Langnes, 9037 Troms $\varnothing$, Norway \\ ${ }^{2}$ Norwegian Polar Institute, P.O. Box 6606 Langnes, 9296 Troms $\varnothing$, Norway
}

Correspondence: Ingrid Leirvik Olsen (ingrid.l.olsen@ uit.no)

Received: 19 November 2019 - Discussion started: 13 January 2020

Revised: 16 October 2020 - Accepted: 22 October 2020 - Published: 4 December 2020

\begin{abstract}
The presence of a grounded Greenland Ice Sheet on the northeastern part of the Greenland continental shelf during the Last Glacial Maximum is supported by new swath bathymetry and high-resolution seismic data, supplemented with multi-proxy analyses of sediment gravity cores from Store Koldewey Trough. Subglacial till fills the trough, with an overlying drape of maximum $2.5 \mathrm{~m}$ thick glacierproximal and glacier-distal sediment. The presence of megascale glacial lineations and a grounding zone wedge in the outer part of the trough, comprising subglacial till, provides evidence of the expansion of fast-flowing, grounded ice, probably originating from the area presently covered with the Storstrømmen ice stream and thereby previously flowing across Store Koldewey Island and Germania Land. Grounding zone wedges and recessional moraines provide evidence that multiple halts and/or readvances interrupted the deglaciation. The formation of the grounding zone wedges is estimated to be at least 130 years, while distances between the recessional moraines indicate that the grounding line locally retreated between 80 and $400 \mathrm{~m} \mathrm{yr}^{-1}$ during the deglaciation, assuming that the moraines formed annually. The complex geomorphology in Store Koldewey Trough is attributed to the trough shallowing and narrowing towards the coast. At a late stage of the deglaciation, the ice stream flowed around the topography on Store Koldewey Island and Germania Land, terminating the sediment input from this sector of the Greenland Ice Sheet to Store Koldewey Trough.
\end{abstract}

\section{Introduction}

The Greenland Ice Sheet (GrIS) is the second largest ice sheet on Earth storing 2.9 million cubic kilometers $\left(\mathrm{km}^{3}\right)$ of ice (AMAP, 2009). The GrIS has experienced increasing ice loss during the last decades, contributing $0.6 \pm 0.1 \mathrm{~mm} \mathrm{yr}^{-1}$ to global sea-level rise between 2000 and 2010 (Fürst et al., 2015). About $16 \%$ of the GrIS is presently drained via marine-terminating outlet glaciers in NE Greenland, mostly through the Northeast Greenland Ice Stream (NEGIS) (Joughin et al., 2000) consisting of three main outlets: $79^{\circ}$ Glacier, Zachariae Isstrøm and Storstrømmen (e.g., Rignot and Kanagaratnam, 2006) (Fig. 1). A future warming global climate, which will be particularly strong in the Arctic (Serreze and Francis, 2006), will possibly lead to a reduced seaice cover adjacent to the glacier termini and subsequent accelerated melting of the ice sheet in NE Greenland (Bendtsen et al., 2017). This could cause an instability and possibly irreversible loss of the GrIS, which has - together with the West Antarctic Ice Sheet (WAIS) - been identified as a tipping element in the Earth's climate system (Lenton et al., 2008). A complete meltdown of these ice sheets can potentially lead to a global sea-level rise of 7.3 (GrIS) and $3.2 \mathrm{~m}$ (WAIS) (Bamber et al., 2001, 2009), causing severe consequences for coastal societies (IPCC, 2018). However, precise predictions of future evolvement of the GrIS remains difficult (Nick et al., 2013). A better understanding of the development of glaciers in response to past climate changes, e.g., from the Last Glacial Maximum (LGM; ca. 26.5-19 ka, Clark et al., 2009) towards the present, is needed to validate and improve numerical models focusing on present processes, as well as the future development of glaciers and ice sheets. 

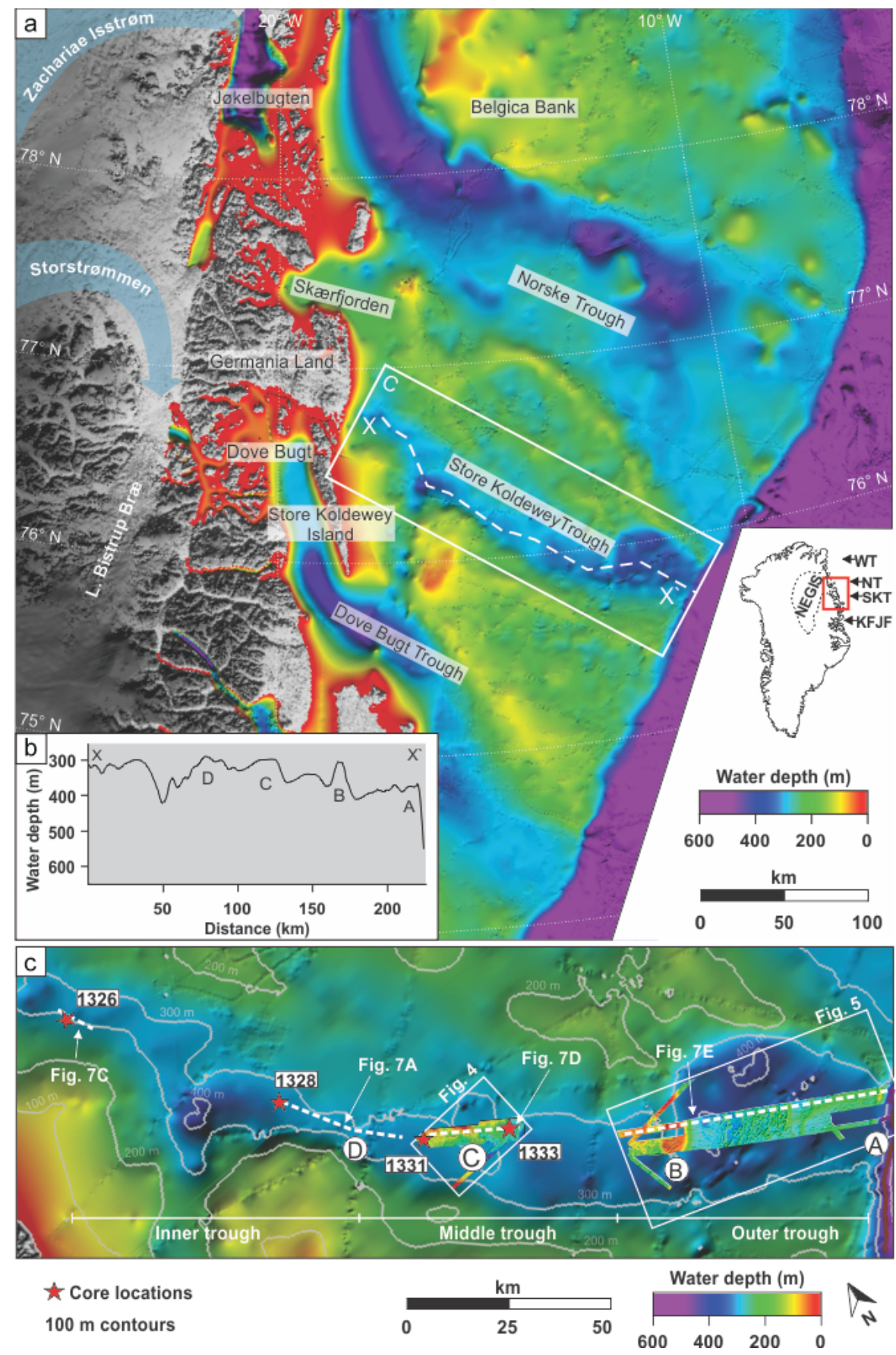

Figure 1. (a) Overview of the regional bathymetry and the hinterland topography of NE Greenland (from IBCAO v.4.0; Jakobsson et al., 2020) including geographical names. The small map shows Greenland and the outline of the NEGIS, with the red box showing the study area detailed in panel (a). The locations of Westwind Trough (WT), Norske Trough (NT), Store Koldewey Trough (SKT) and Kejser Franz Josef Fjord (KFJF) are indicated. The white dashed line shows the location of the bathymetric profile shown in panel (b). (b) Bathymetric profile along the central axis of Store Koldewey Trough. The labels A-D show the locations of interpreted grounding zone wedges as described by Laberg et al. (2017). (c) Large-scale bathymetry of Store Koldewey Trough (from IBCAO v.4.0; Jakobsson et al., 2020) including the swath bathymetry data analyzed in this study. The labels A-D represent grounding zone wedges (adapted from Laberg et al., 2017); red stars show core locations. 
The reconstruction of the GrIS configuration and dynamics from marine geoscientific data, including maximum extent during the LGM, as well as the timing and dynamics of the deglaciation, has been addressed in multiple studies (e.g., Andrews et al., 1998; Bennike et al., 2002; Dowdeswell et al., 1994, 2014; Funder et al., 2011a; Hogan et al., 2011, 2016, 2020; Hubberten et al., 1995; Ó Cofaigh et al., 2013). However, these reconstructions focus primarily on the southern and western sectors offshore Greenland, and reconstructions from offshore NE Greenland remain sparse (Arndt, 2018; Arndt et al., 2017; Evans et al., 2002; Laberg et al., 2017; Stein et al., 1996; Winkelmann et al., 2010). Marine geoscientific studies suggest that the northeastern sector of the GrIS extended all the way to the shelf edge during the last glacial based on observations of subglacial and ice-marginal depositional landforms, including mega-scale glacial lineations, grounding zone wedges and recessional terminal moraines (Arndt, 2018; Arndt et al., 2015, 2017; Evans et al., 2009; Laberg et al., 2017; Ó Cofaigh et al., 2004).

Laberg et al. (2017) presented glacial landforms interpreted as retreat moraines in the outermost part of Store Koldewey Trough (Fig. 1), suggesting a stepwise early deglaciation likely triggered by an increase in ocean temperature. However, in order to precisely link retreat events with external forcing (e.g., climate or oceanic changes), an absolute chronology for the deglaciation is required. According to Evans et al. (2002), breakup and retreat of the GrIS further to the south, outside Kejser Franz Joseph Fjord (Kaiser Franz Joseph Fjord; for location, see Fig. 1), commenced after $18.4 \mathrm{kacalBP}$ (for age calibration see Material and methods chapter), with the ice abandoning the mid-shelf before $15.5 \mathrm{kacalBP}$ and the inner shelf being ice-free before $10.3 \mathrm{kacal}$ BP. Cosmogenic nuclide dating on Store Koldewey Island, located west of Store Koldewey Trough (Fig. 1), reveals that the ice front retreated from the area ca. $12.7 \mathrm{ka}$ (Skov et al., 2020), whereas the ice front rested east of the present coastline of Germania Land until ca. $10 \mathrm{ka}$ cal BP (Landvik, 1994). By $8.3 \mathrm{ka} \mathrm{cal} \mathrm{BP}$ the ice front had retreated close to its present position, and after further recession Germania Land became an island around $5.5 \mathrm{ka}$ cal BP. Storstrømmen readvanced again ca. $1 \mathrm{ka} \mathrm{cal} \mathrm{BP,}$ reaching its present position during the Little Ice Age (Weidick et al., 1996).

The overall objective of this paper is to provide new knowledge about the evolution of the northeastern part of the GrIS based on new acoustic data (multibeam bathymetry and chirp seismic) and sediment cores. These new data sets expand and complement existing data in one of the largest glacial troughs offshore NE Greenland, i.e., the Store Koldewey Trough. More specifically, the aims are to (1) reconstruct the ice drainage pathways, ice sheet extent, and ice stream dynamics of this sector of the GrIS overlying Store Koldewey Trough during the LGM and the deglaciation; and (2) discuss the post-glacial marine environmental conditions of the trough.

\section{Regional setting}

The large-scale morphology of the NE Greenland continental shelf is characterized by several large cross-shelf troughs separated by shallower banks and shoals (Fig. 1). The troughs are characteristic features of formerly glaciated continental shelves, interpreted as glacially over-deepened landforms acting as conduits for fast-flowing ice streams eroding into the subglacial bed (e.g., Vorren et al., 1988; Canals et al., 2000; Batchelor and Dowdeswell, 2014), while inter-trough banks are interpreted to have been covered by slower flowing ice, consequently experiencing less erosion (Klages et al., 2013; Ottesen and Dowdeswell, 2009).

The east coast of Greenland is presently largely influenced by the southward-flowing East Greenland Current carrying cold, fresh surface polar water and sea ice from the Arctic Ocean together with warmer modified Atlantic Intermediate Water (Aagaard and Coachman, 1968; Hopkins, 1991). An increased inflow of warm Atlantic Intermediate Water into East Greenland troughs and fjords is proposed to influence the submarine melt rates, causing an instability at the grounding line of marine-terminating outlet glaciers (Khan et al., 2014; Mayer et al., 2018), e.g., the $79^{\circ}$ Glacier (Straneo and Heimbach, 2013; Wilson and Straneo, 2015).

Store Koldewey Trough is a $\sim 210 \mathrm{~km}$ long, $30-40 \mathrm{~km}$ wide and up to $400 \mathrm{~m}$ deep, NW-SE-oriented cross-shelf trough located at $\sim 76^{\circ} \mathrm{N}$ offshore NE Greenland (Fig. 1). It is divided into an inner-, middle- and outer trough (Fig. 1c), with a sinuous centerline terminating at the shelf edge. A bathymetric profile along the axis of Store Koldewey Trough reveals that it differs from most troughs offshore NE Greenland, because it overall deepens towards the shelf break (Fig. 1b). In addition, Store Koldewey Trough is the only trough on the NE Greenland continental shelf without a fjord continuation; it terminates near Germania Land and Store Koldewey Island to the west (Fig. 1a).

Laberg et al. (2017) identified an assemblage of glacigenic landforms in outer Store Koldewey Trough, including megascale glacial lineations and rhombohedral and transverse ridges with variable dimensions. From the landform assemblage, it was inferred that grounded ice expanded to the shelf edge during the last glacial. Four prominent transverse ridges located in the outer, middle and inner trough were interpreted as grounding zone wedges deposited in front of the GrIS at temporary stillstands and/or readvances during the last deglaciation (see labels A-D in Fig. 1b, c). Similar landform assemblages are also identified in other troughs along the northeastern continental shelf of Greenland (Arndt, 2018; Arndt et al., 2015) as well as on other formerly glaciated continental shelves (e.g., Ottesen et al., 2005; Winsborrow et al., 2010; Jakobsson et al., 2012a; Bjarnadóttir et al., 2013; Andreassen et al., 2014; Batchelor and Dowdeswell, 2014). However, details about how these shelf-break-terminating parts of the NEGIS retreated landwards remain unknown, as only very limited areas are mapped by high-resolution swath 
Table 1. Core locations, water depths and recoveries.

\begin{tabular}{lrrrr}
\hline Core ID & $\begin{array}{r}\text { Latitude } \\
\left({ }^{\circ} \mathrm{N}\right)\end{array}$ & $\begin{array}{r}\text { Longitude } \\
\left({ }^{\circ} \mathrm{W}\right)\end{array}$ & $\begin{array}{r}\text { Water } \\
\text { depth }(\mathrm{m})\end{array}$ & $\begin{array}{r}\text { Recovery } \\
(\mathrm{cm})\end{array}$ \\
\hline HH17-1326-GC-TUNU & $76^{\circ} 21.55^{\prime}$ & $17^{\circ} 05.54^{\prime}$ & 294 & 75 \\
HH17-1328-GC-TUNU & $76^{\circ} 14.07^{\prime}$ & $16^{\circ} 05.42^{\prime}$ & 316 & 195 \\
HH17-1331-GC-TUNU & $76^{\circ} 06.50^{\prime}$ & $15^{\circ} 07.25^{\prime}$ & 306 & 110 \\
HH17-1333-GC-TUNU & $76^{\circ} 00.41^{\prime}$ & $14^{\circ} 09.36^{\prime}$ & 345 & 169 \\
\hline
\end{tabular}

bathymetry (Arndt, 2018; Arndt et al., 2017; Evans et al., 2009; Laberg et al., 2017; Winkelmann et al., 2010).

\section{Material and methods}

Acoustic data, including swath bathymetry and highresolution seismic data, as well as four sediment gravity cores were collected during cruises arranged by the TUNU program (Christiansen, 2012) using R/V Helmer Hanssen of UiT The Arctic University of Norway in 2013, 2015 and 2017.

The swath bathymetry data were acquired using hullmounted Kongsberg Maritime Simrad EM 300 and 302 multibeam echo sounders in 2013/2015 and 2017, respectively. Sound velocity profiles for the water column were derived from CTD (conductivity-temperature-depth) casts prior to and during the bathymetric surveys. High-resolution seismic profiles were acquired with a hull-mounted EdgeTech 3300-HM (chirp) sub-bottom profiler simultaneously with the swath bathymetry data, using a pulse frequency of $2-8 \mathrm{kHz}$. Visualization and interpretation of the Chirp and swath bathymetry data were performed using Petrel 2018 and Global Mapper 19.

The acoustic data sets consist of previously unpublished data from the middle trough acquired in 2017, and data from the outer trough previously presented by Laberg et al. (2017). Systematic mapping and outlining of landform elements in Store Koldewey Trough were conducted on the entire swath bathymetry data set, including some re-interpretations of the outer trough (see Sect. 4.2.4). The landforms were mapped and classified based on shape, size, arrangement and orientation. The sediment volumes of the grounding zone wedges were calculated as trapezoid prisms, using a mean thickness and length obtained from the acoustic data. Due to the limited data coverage, we use a similar approach as Jakobsson et al. (2012a) and calculate the volume per $1 \mathrm{~m}$ grounding line width $\left(\mathrm{m}^{3} \mathrm{~m}^{-1}\right)$. Since the Chirp sub-bottom signal was unable to penetrate to the bases of the grounding zone wedges, a flat base beneath the proximal sides of the wedges was assumed.

The sediment gravity cores (HH17-1326, HH17-1328, HH17-1331 and HH17-1333) were retrieved from 294 to $345 \mathrm{~m}$ water depth along a transect extending from the inner to middle Store Koldewey Trough using a $6 \mathrm{~m}$ long steel bar- rel (Fig. 1; Table 1). Coring sites were chosen with the purpose of penetrating a stratigraphic sequence including subglacial and glacimarine deposits.

Prior to opening, the physical properties of the sediments were measured using the Geotek Multi-Sensor Core Logger, with a $10 \mathrm{~mm}$ step size and $10 \mathrm{~s}$ measuring time. The cores were stored for $1 \mathrm{~d}$ in the laboratory prior to the measurements to allow the sediments to adjust to room temperature as temperature changes can affect the physical properties (Weber et al., 1997). After splitting, color images were acquired with a Jai L-107CC 3 CCD RGB line scan camera installed on an Avaatech XRF core scanner. Furthermore, X-radiographs were taken with a Geotek MSCL-XCT X-ray core imaging system. A systematic description of the sediment surface was carried out, and colors were determined visually using the Munsell Soil Color Chart (Munsell, 2000). The cores contained insufficient amounts of dateable material for a chronology to be established, a common problem from areas where cold polar waters lead to both relatively few calcareous organisms and dissolution of the carbonate material (e.g., Andrews et al., 1999; Zamelczyk et al., 2012).

Grain-size analyses were performed using a Beckman Coulter LS 13320 laser particle size analyzer, measuring the range from 0.04 to $2000 \mu \mathrm{m}$. Particles larger than $2000 \mu \mathrm{m}$ were removed by a sieve and are presented as clasts in the lithological logs. Prior to the analyses, chemical treatment of the samples using $\mathrm{HCl}$ and $\mathrm{H}_{2} \mathrm{O}_{2}$ was conducted to remove carbonates and organic content, respectively. Distilled water was added to the samples before being shaken for $24 \mathrm{~h}$. Furthermore, two drops of Calgon solution were added to the samples before being placed in an ultrasound bath for $5 \mathrm{~min}$ in order to disintegrate aggregates of particles. Each sample was analyzed three times and the particle size statistics were calculated using GRADISTAT v. 8.0 (Blott and Pye, 2001).

Age calibration for the radiocarbon ages cited in this study was performed using the CALIB 8.20 software (Stuiver et al., 2020), applying the Marine20 calibration curve (Heaton et al., 2020) with $\Delta R=0 \pm 50$, as recommended by Andrews et al. (2016). All dates are presented in calibrated years before present (ka cal BP), where zero year BP is $1950 \mathrm{CE}$. 


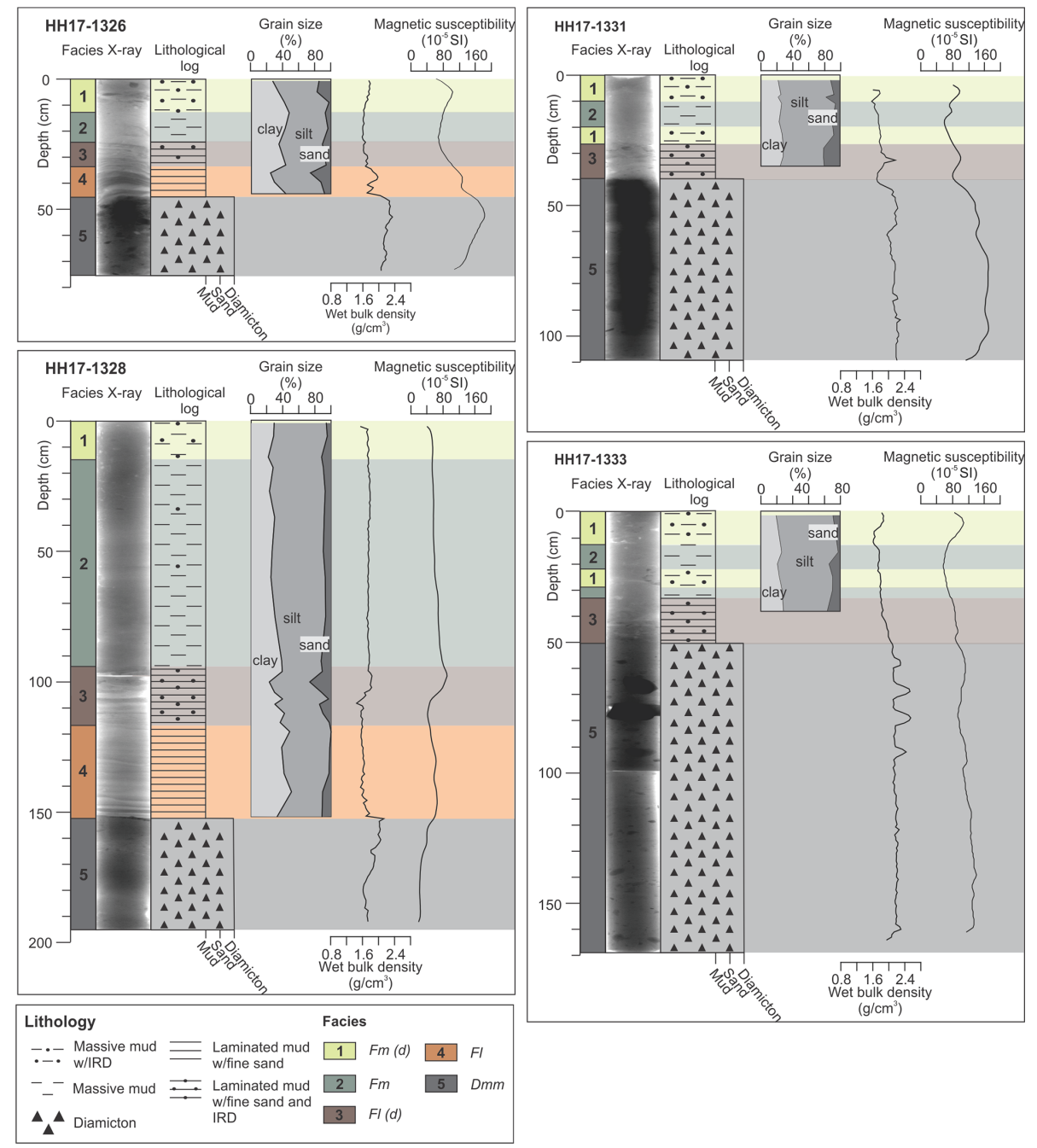

Figure 2. Lithofacies logs, X-radiographs, grain-size distribution and physical properties for the cores from the inner and middle Store Koldewey Trough. The darker grey tones in the X-radiographs reflect higher density, whereas brighter grey tones reflect lower density. The locations of the sediment cores are shown in Fig. 1c.

\section{Results}

\subsection{Lithostratigraphy of the uppermost trough strata}

Five lithofacies are defined based on the lithological composition, sedimentary structures and physical properties (Figs. 2 and 3). The properties of the different facies are summarized in Table 2.

\subsubsection{Facies 5 - diamicton $(D m m)$}

The lowermost facies in all four cores comprises a very dark gray, massive, matrix-supported diamicton with a sandy mud matrix and high amounts of randomly oriented clasts (Figs. 2 and 3; Table 2). The upper boundary is sharp, and bioturbation is absent. The magnetic susceptibility varies between each core, with the highest in HH17-1326 and lowest in HH17-1328. The wet bulk density is generally higher than in the overlying facies, suggesting over-consolidation of the sediments.

Based on the diamictic composition of these deposits, the high amounts of clasts, absence of bioturbation and a considerable consolidation of the sediments, we suggest that the facies represents diamictic subglacial debris/basal till deposited at the base of an ice stream from the GrIS (compare with Evans et al., 2006).

\subsubsection{Facies 4 - interlaminated glacimarine sediments $(\boldsymbol{F l})$}

Facies 4 is present in the two cores in the inner trough: HH17-1326 and HH17-1328, with thicknesses of 12 and $35 \mathrm{~cm}$, respectively (Figs. 2 and 3, Table 2). The facies consists of dark gray laminated mud with fine sandy layers. Bioturbation and clasts are absent. The upper unit boundary 

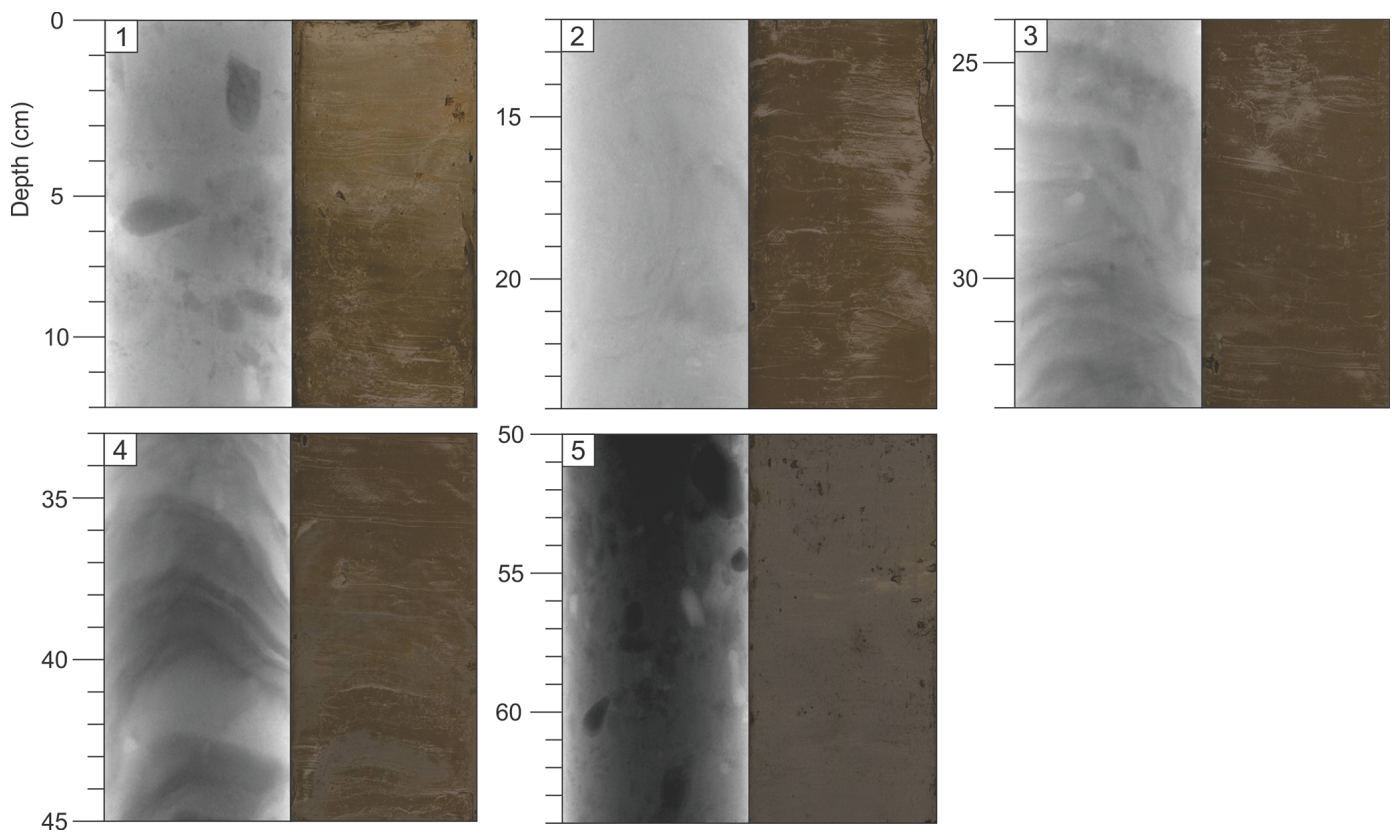

Figure 3. X-radiographs with associated photographs of representative lithofacies in this study, all from core HH17-1326. (1) Massive mud with ice-rafted debris (IRD) $(F m(d))$. (2) Massive mud $(F m)$. (3) Laminated mud with occasional IRD $(F l(d))$. (4) Laminated mud $(F l)$. (5) Diamicton $(\mathrm{Dmm})$. The darker grey tones on the X-radiographs reflect higher density, whereas brighter grey tones reflect lower density.

is gradational and defined by the appearance of clasts. The wet bulk density is medium, while the magnetic susceptibility varies with a decrease in HH17-1326 and an increase in HH17-1328 relative to the underlying unit.

Facies 4 is interpreted to contain glacier-proximal glacimarine sediments deposited from suspension settling, where the stratification of the sediments reflects variations in the current strength of the water masses emanating from the ice margin. Such laminated to massive sandy muds are typically overlying basal diamictons (i.e., facies 5) in glaciated continental margin and fjord settings (e.g., Domack et al., 1999; Prothro et al., 2018; Smith et al., 2019). The lack of clasts interpreted as ice-rafted debris (IRD) in ice-proximal settings may have several explanations, which will be discussed further below (see Sect. 5.2).

\subsubsection{Facies 3 - interlaminated glacimarine sediments with occasional IRD $(F l(d))$}

Facies 3 occurs in all cores. It is $9-23 \mathrm{~cm}$ thick and consists of dark gray laminated mud with fine-sand layers and clasts (Figs. 2 and 3; Table 2). The clasts, interpreted as IRD, appear in diamict layers. The unit has a sharp or gradational lower boundary overlying either facies 5 or 4, respectively, while the upper boundary is gradational. The properties are similar to facies 4, with medium-high wet bulk density. However, the magnetic susceptibility varies between the cores.

Facies 3 is interpreted to represent a glacier-proximal setting with glacimarine sediments containing IRD deposited in episodic calving events. The sediments are thought to have been deposited in glacimarine conditions, reflecting a calving front in a more distal setting where IRD becomes a more dominant component at the expense of suspension settling (cf. Smith et al., 2019), compared to facies 4. Another possible explanation is that the facies reflects deposition from melt-out of englacial debris at the grounding line, similar to the facies ascribed as "stratified diamicton" by Smith et al. (2019).

\subsubsection{Facies 2 - massive glacimarine sediments $(\mathrm{Fm})$}

Massive olive gray to dark gray mud with little to moderate bioturbation and rare clasts composes facies 2 . The facies is $10-80 \mathrm{~cm}$ thick and occurs in all four sediment cores (Figs. 2 and 3; Table 2); facies 2 overlies facies 3 in all cores, except for core HH17-1331, where it overlies facies 1. In core HH17-1333, facies 2 alternates with facies 1 . The lower and upper unit boundaries are gradational in all cores. The physical properties, including wet bulk density and magnetic susceptibility, vary slightly within the facies and between the cores.

The facies is interpreted to reflect suspension settling in an ice-distal glacimarine environment with limited iceberg or sea-ice rafting. With increased distance from the grounding line, deposition from turbid meltwater plumes typically grade into more massive, bioturbated mud (Ó Cofaigh and Dowdeswell, 2001; Prothro et al., 2018; Smith et al., 2019). The rare amount of IRD within the massive mud may be a consequence of the appearance of warm surface water during the early Holocene causing prolonged open-water conditions 
Table 2. Overview of the main properties and compositional characteristics of the lithofacies, as well as depositional environments.

\begin{tabular}{|c|c|c|c|c|c|}
\hline Lithofacies & $5-D m m$ & $4-F l$ & $3-F l(d)$ & $2-F m$ & $1-F m(d)$ \\
\hline $\begin{array}{l}\text { HH17-1326-GC-TUNU } \\
(75 \mathrm{~cm})\end{array}$ & $45 \mathrm{~cm}$ - end of core & $33-45 \mathrm{~cm}$ & $24-33 \mathrm{~cm}$ & $12-24 \mathrm{~cm}$ & Top of core $-12 \mathrm{~cm}$ \\
\hline $\begin{array}{l}\text { HH17-1328-GC-TUNU } \\
(195 \mathrm{~cm})\end{array}$ & $152 \mathrm{~cm}-$ end of core & $117-152 \mathrm{~cm}$ & $94-117 \mathrm{~cm}$ & $14-94 \mathrm{~cm}$ & Top of core $-14 \mathrm{~cm}$ \\
\hline $\begin{array}{l}\text { HH17-1331-GC-TUNU } \\
(110 \mathrm{~cm})\end{array}$ & $40 \mathrm{~cm}$ - end of core & Absent & $26-40 \mathrm{~cm}$ & $10-20 \mathrm{~cm}$ & $\begin{array}{l}\text { Top of core }-10 \mathrm{~cm} \text {, } \\
20-26 \mathrm{~cm}\end{array}$ \\
\hline $\begin{array}{l}\text { HH17-1333-GC-TUNU } \\
(169 \mathrm{~cm})\end{array}$ & $51 \mathrm{~cm}$ - end of core & Absent & $33-51 \mathrm{~cm}$ & $12-22 \mathrm{~cm}, 28-33 \mathrm{~cm}$ & $\begin{array}{l}\text { Top of core }-12 \mathrm{~cm} \text {, } \\
22-28 \mathrm{~cm}\end{array}$ \\
\hline Lithology & $\begin{array}{l}\text { Diamicton, massive } \\
\text { and matrix supported } \\
\text { with a sandy mud ma- } \\
\text { trix; } \\
\text { randomly oriented } \\
\text { clasts }\end{array}$ & $\begin{array}{l}\text { Laminated mud with } \\
\text { fine sandy layers }\end{array}$ & $\begin{array}{l}\text { Laminated mud with } \\
\text { fine sandy layers and } \\
\text { IRD }\end{array}$ & $\begin{array}{l}\text { Massive mud with } \\
\text { rare IRD }\end{array}$ & $\begin{array}{l}\text { Massive mud with } \\
\text { occasional IRD }\end{array}$ \\
\hline $\begin{array}{l}\text { Color (Munsell Soil } \\
\text { Color Chart) }\end{array}$ & $\begin{array}{l}\text { Very dark gray } \\
(2.5 \mathrm{Y} 3 / 0)\end{array}$ & Dark gray (10YR 4/1) & Dark gray (10YR 4/1) & $\begin{array}{l}\text { Olive gray (5Y (/2); } \\
\text { dark gray }(10 \mathrm{YR} 4 / 1)\end{array}$ & $\begin{array}{l}\text { Dark grayish brown } \\
(2.5 \mathrm{Y} 4 / 2) \text {; dark olive } \\
\text { gray }(5 \mathrm{Y} 3 / 2) ; \\
\text { olive gray }(5 \mathrm{Y}(4 / 2) \text {; } \\
\text { brown }(7.5 \mathrm{YR} 4 / 2)\end{array}$ \\
\hline Clast amount & High amounts & Absent & Scattered in layers & Rare & $\begin{array}{l}\text { Sections containing } \\
\text { clasts }\end{array}$ \\
\hline Bioturbation & Absent & Absent & Absent & Little to moderate & Little \\
\hline Lower unit boundary & Not recovered & Sharp & Gradational or sharp & Gradational & Gradational \\
\hline Upper unit boundary & Sharp & Gradational & Gradational & Gradational & Top of core \\
\hline Bulk density $\left(\mathrm{g} \mathrm{cm}^{-3}\right)$ & $1.61-2.55$ & $1.54-2.03$ & $1.60-2.15$ & $1.60-1.84$ & $1.55-1.78$ \\
\hline $\begin{array}{l}\text { Magnetic susceptibility } \\
\left(10^{-5} \mathrm{SI}\right)\end{array}$ & $20-182$ & $46-148$ & $66-100$ & $53-114$ & $41-106$ \\
\hline $\begin{array}{l}\text { Sedimentary } \\
\text { environment }\end{array}$ & Subglacial till & $\begin{array}{l}\text { Proximal glacimarine } \\
\text { sedimentation from } \\
\text { suspension settling; } \\
\text { sub-ice shelf environ- } \\
\text { ment }\end{array}$ & $\begin{array}{l}\text { Proximal glacimarine } \\
\text { sedimentation from } \\
\text { suspension settling; } \\
\text { ice rafting is relatively } \\
\text { dominant }\end{array}$ & $\begin{array}{l}\text { Distal glacimarine sedi- } \\
\text { mentation dominated } \\
\text { by suspension settling; } \\
\text { ice rafting is limited }\end{array}$ & $\begin{array}{l}\text { Distal glacimarine sedi- } \\
\text { mentation dominated } \\
\text { by suspension settling; } \\
\text { enhanced ice rafting }\end{array}$ \\
\hline
\end{tabular}

and limited iceberg rafting on the shelf (Müller et al., 2012; Syring et al., 2020).

\subsubsection{Facies 1 - massive glacimarine sediments with $\operatorname{IRD}(\operatorname{Fm}(d))$}

The uppermost facies in all of the studied cores consists of massive mud with clast-containing intervals, the latter interpreted to be IRD (Figs. 2 and 3; Table 2). Facies 1 occurs twice in core HH17-1331 and HH17-1333, lying directly above facies 3 and 2 . Sediment color alternates between brown and dark grayish brown, as well as olive gray to dark olive gray. Facies 1 is generally coarser than facies 2 . Peaks in the magnetic susceptibility correspond to the depths with highest abundance of coarser material. The wet bulk density is similar to the underlying facies 2 .

Facies 1 is interpreted to have been deposited in a similar environment as facies 2. Deposition of IRD can occur from dropping and dumping (see Vorren et al., 1983); i.e., dump- ing from a single iceberg or ice flow may be misinterpreted as enhanced ice rafting. However, since we identify increased amounts of IRD in all four cores, we are confident that facies 1 reflects increased ice rafting at a regional scale, most probably related to the neoglacial cooling trend (cf. Syring et al., 2020).

\subsection{Submarine landforms: glacial-deglacial ice sheet dynamics}

The swath bathymetry data from the middle (Fig. 4) and outer (Fig. 5) Store Koldewey Trough reveal glacigenic landforms interpreted to reflect various stages of ice sheet extent, flow dynamics and retreat patterns.

\subsubsection{Streamlined landforms - glacial lineations}

Streamlined, trough-parallel grooves and ridges occur in the middle and outer trough (Figs. 4, 5 and 6a and c), terminating close to the shelf edge. Individual ridges have 

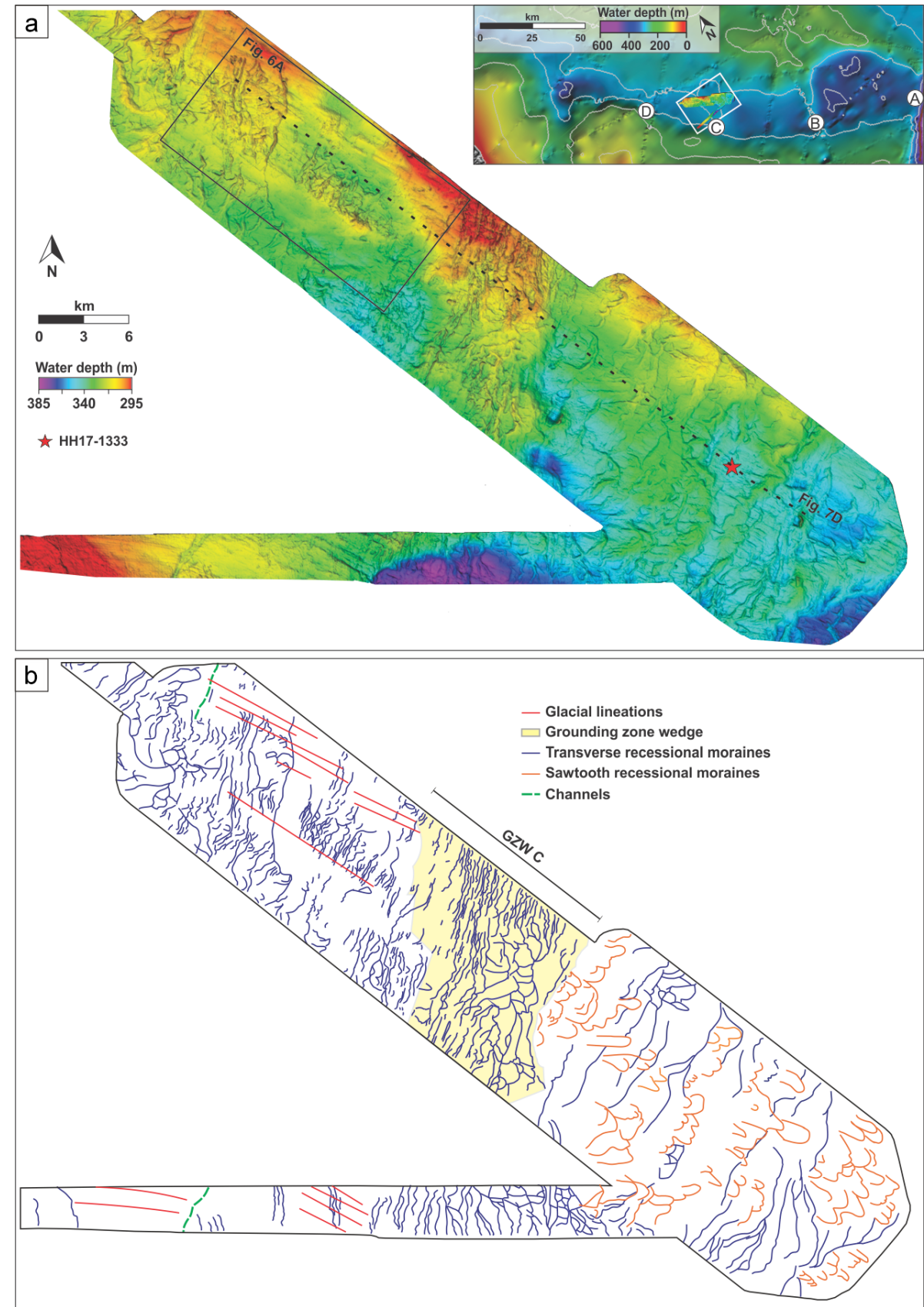

Figure 4. (a) Swath bathymetry map from the middle part of Store Koldewey Trough. The locations of grounding zone wedges A-D are indicated in the inset map (bathymetry from IBCAO v.4.0; Jakobsson et al., 2020). (b) Interpretation and distribution of landforms.

Table 3. Dimensions of submarine landforms.

\begin{tabular}{lrrrr}
\hline & Length $(\mathrm{km})$ & Width $(\mathrm{m})$ & Relief $(\mathrm{m})$ & Spacing $(\mathrm{m})$ \\
\hline Glacial lineations & $1.5-9$ & $150-500$ & $4-8$ & $200-700$ \\
Grounding zone wedges & N/A & $3500-10000$ & $35-100$ & $45000-60000$ \\
Transverse recessional moraines & N/A & $<2200$ & $<50$ & $50-500$ \\
Sawtooth recessional moraines & $<1.3$ & $170-1100$ & $5-30$ & N/A \\
Channels & N/A & $150-300$ & $3-10$ & N/A \\
\hline
\end{tabular}



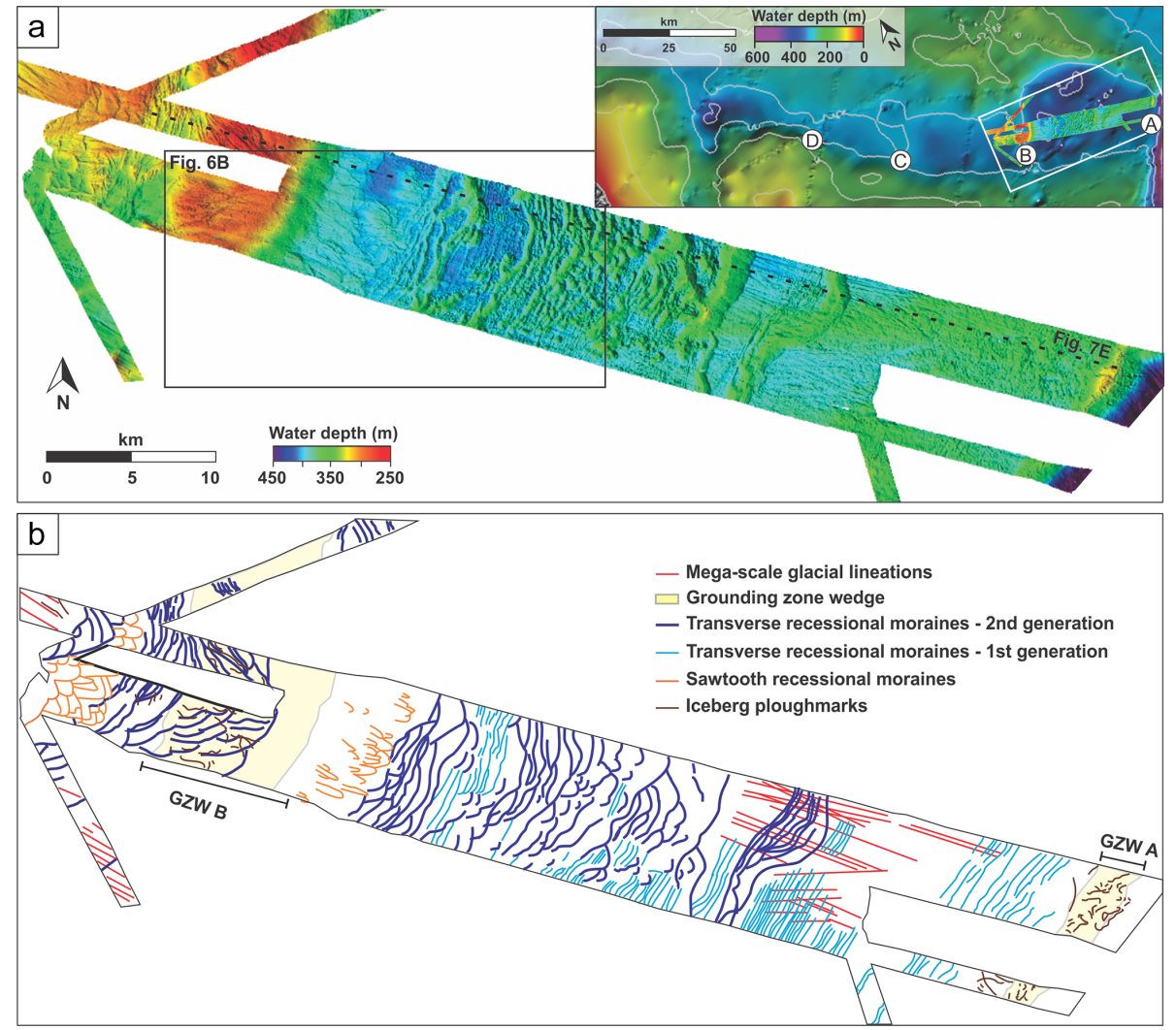

Figure 5. (a) Swath bathymetry map from the outer part of Store Koldewey Trough. The locations of grounding zone wedges A-D are indicated in the inset map (bathymetry from IBCAO v.4.0; Jakobsson et al., 2020). (b) Interpretation and distribution of landforms modified after Laberg et al. (2017), supplemented with new data.

widths of $150-500 \mathrm{~m}$ and reliefs between $4-8 \mathrm{~m}$ (Table 3). They occur in clusters with spacing from 200 to $700 \mathrm{~m}$. The grooves and ridges are partly eroded and/or overprinted by other landforms, making the determination of their maximum lengths challenging. Their minimum lengths range from 1.5 to $>9 \mathrm{~km}$, and their length/width ratios generally exceed $10: 1$, with the highest ratios occurring in the outer trough. High-resolution seismic data show that the ridges are acoustically transparent, a property that is characteristic for basal till (e.g., Ó Cofaigh et al., 2007).

Based on the spatial distribution, dimensions and orientations, we interpret the grooves and ridges as glacial lineations formed subglacially at the base of a fast-flowing, grounded ice stream (Clark, 1993; King et al., 2009; Spagnolo et al., 2014) draining the GrIS towards the shelf break. The lineations in the outer trough have longer length/width ratios, are more densely spaced and are thus termed mega-scale glacial lineations. Similar streamlined landforms have been described on the seafloor of other formerly glaciated margins where they have been interpreted to indicate the presence of grounded ice streams (e.g., Canals et al., 2000; Ottesen et al., 2005; Evans et al., 2009; Rydningen et al., 2013; Andreassen et al., 2014; Hogan et al., 2016; Arndt, 2018).

\subsubsection{Large transverse ridges - grounding zone wedges}

Four prominent bathymetric sills, interpreted as grounding zone wedges A-D from multibeam data and IBCAO 3.0 (Jakobsson et al., 2012b) by Laberg et al. (2017), are present within the trough (Figs. 1b, c and 7). These authors presented acoustic data from wedges $\mathrm{A}$ and $\mathrm{B}$, while the data from our study provide new information about wedge $\mathrm{C}$. The wedges are $35-100 \mathrm{~m}$ high, $3.5-10 \mathrm{~km}$ wide and are spaced $45-60 \mathrm{~km}$ apart from each other (Table 3). Sediment volumes per meter grounding line width are approximately 130000,738000 and $150000 \mathrm{~m}^{3}$ for wedges A, B and C, respectively. The cross-trough extents of the grounding zone wedges exceed the multibeam data coverage. Smaller ridges overprint the grounding zone wedges (Figs. 4, 5 and 6). The bases of the wedges are impossible to identify on our Chirp profiles, but 2-D seismic profiles described by Petersen et al. (2015) reveal a thick Neogene sedimentary succession offshore NE Greenland, thus ruling out that these features are bedrock sills. As such, these large landforms are interpreted to be accumulations of sediments deposited at the grounding line of the ice stream, recording the position of the grounding line during temporary stillstands, either reflecting a relatively long-lasting halt during the general retreat or the termination 

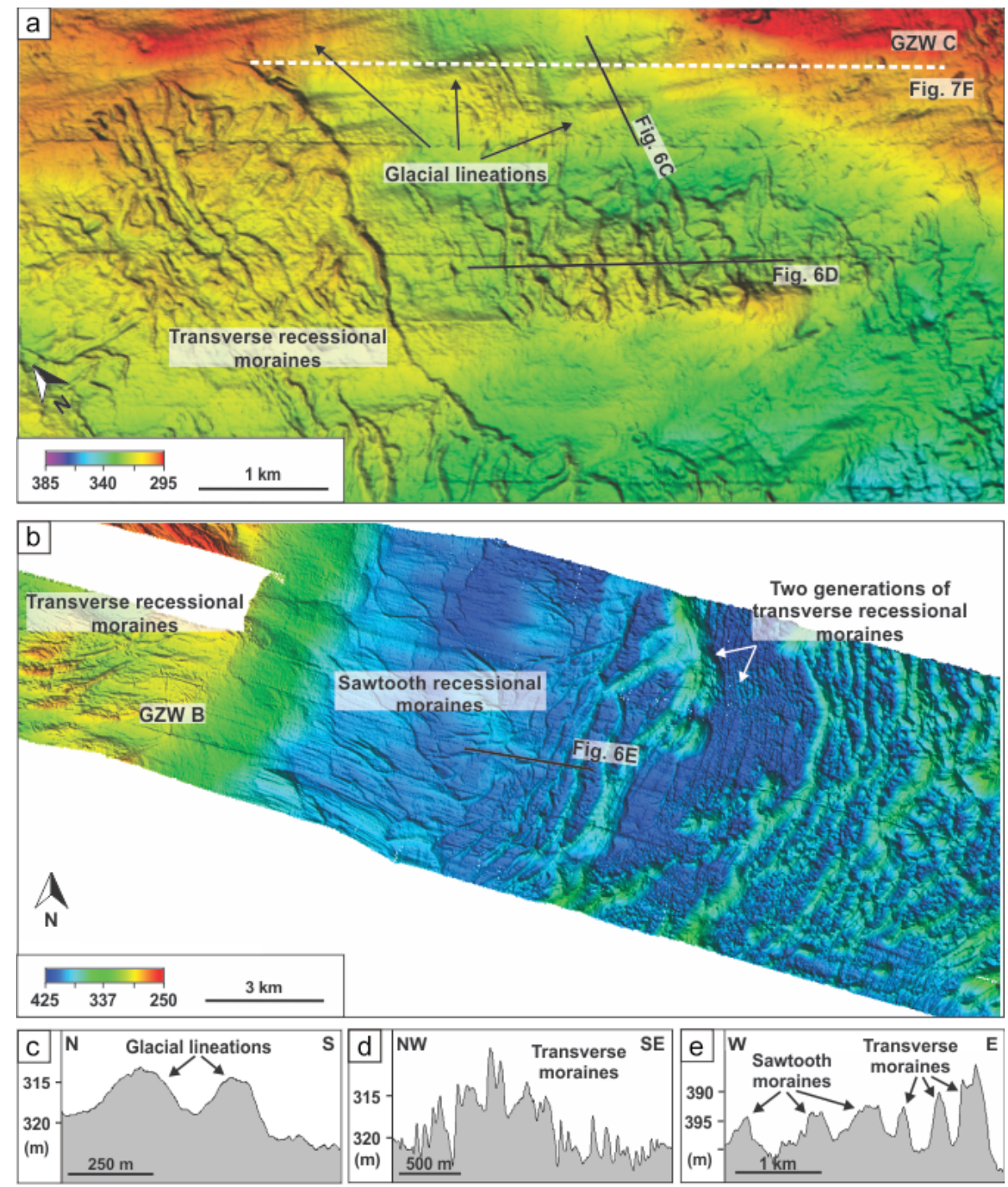

Figure 6. (a) Examples of glacial lineations and transverse recessional moraines. (b) Examples of sawtooth and transverse recessional moraines. (c) Bathymetric cross profile of glacial lineations. (d) Bathymetric cross profile of transverse moraines. (e) Bathymetric profile of sawtooth moraines and transverse moraines.

of a more extensive readvance during a late phase of the last glacial.

\subsubsection{Small transverse ridges - transverse recessional moraines}

Multiple straight to slightly curvilinear transverse/semitransverse ridges are visible on the seafloor of Store Koldewey Trough (Figs. 4, 5, 6 and 7). The ridges are up to $2200 \mathrm{~m}$ wide, have reliefs $<50 \mathrm{~m}$ and have a spacing of 50 $500 \mathrm{~m}$ (Table 3). Some of the ridges superimpose others, implying several generations of ridge formation (Fig. 5). There are two generations of ridges in the outer trough (between grounding zone wedges A and B), where the first generation is spaced $\sim 80 \mathrm{~m}$ apart, while the superimposing ridges are larger and mostly spaced $200-400 \mathrm{~m}$ apart. The spacing of ridges in the middle trough is commonly $100-200 \mathrm{~m}$.

We interpret the curvilinear to straight ridges as recessional moraines formed at the grounding line during overall retreat with repeated short-term stillstands and/or small readvances (cf. Dowdeswell et al., 2008; Ó Cofaigh et al., 2008). The ridge-like features identified on the sub-bottom profiles are acoustically transparent, suggesting a diamictic composition (Stewart and Stoker, 1990) (Fig. 7).

\subsubsection{Curvilinear ridges - sawtooth recessional moraines}

Clusters of curvilinear ridges occur both landward and seaward of grounding zone wedge $\mathrm{B}$ and seaward of grounding zone wedge $C$ (Figs. 4, 5, 6b and 7d, e). These ridges occur 

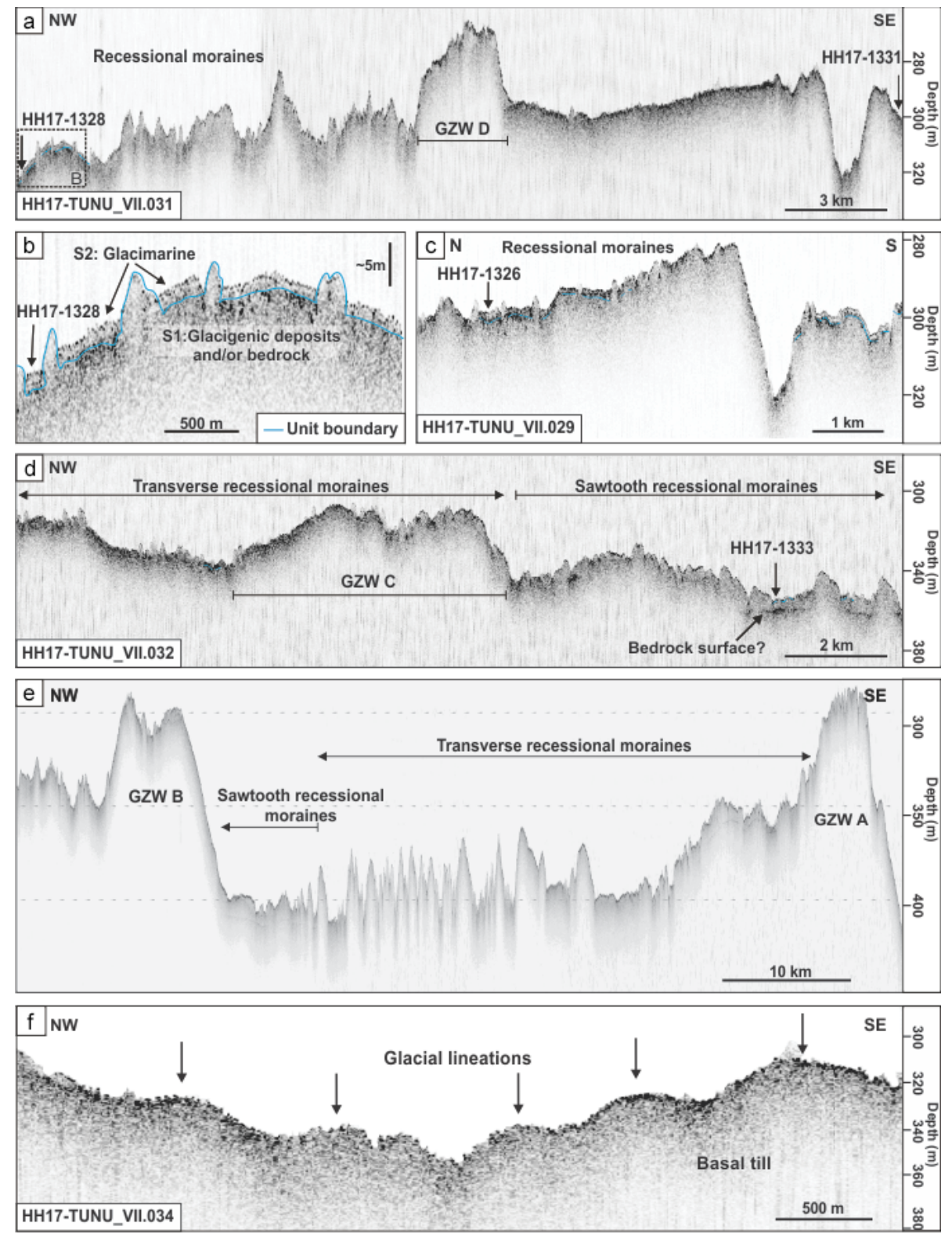

Figure 7. Chirp sub-bottom profiles from Store Koldewey Trough. See Fig. 1c for locations of (a) to (e). (a) Chirp line HH17-TUNU_VII.031 across grounding zone wedge D and recessional moraines from the middle trough area. Projected positions of sediment cores HH17-1328 and HH17-1331 are shown. Black dotted rectangle shows extent of the profile in panel (b). (b) Part of chirp line HH17-TUNU_VII.031 showing a close-up example of the configuration of units S1 and S2. (c) Chirp line HH17-TUNU_VII.029 from the inner part of the trough, with recessional moraines. Projected position of sediment core HH17-1326 is indicated. (d) Chirp line HH17-TUNU_VII.032 across grounding zone wedge $\mathrm{C}$. The locations for transverse recessional moraines, sawtooth recessional moraines and sediment core HH17-1333 are indicated. (e) Chirp line across grounding zone wedge A and B, separated by sawtooth and transverse recessional moraines. Modified from Laberg et al. (2017). (f) Part of chirp sub-bottom profile HH17-TUNU_VII.034 showing the acoustically transparent deposits interpreted as basal till/glacial lineations. The ridges of the latter are indicated with arrows. For location, see Fig. $6 a$.

often closely spaced, exhibiting a sawtooth pattern in plan view. Many of the features continue as long moraine ridges oriented sub-parallel to the ice-flow direction. Bifurcations and cross-cutting patterns occur. Individual ridges are up to $1.3 \mathrm{~km}$ long, $170-1100 \mathrm{~m}$ wide and have a relief of $5-30 \mathrm{~m}$ (Table 3). They are typically asymmetrical with a steeper ice- distal slope and a more gentle ice-proximal slope (Fig. 6e). The sawtooth ridges partly superpose and modify the underlying transverse ridges creating locally chaotic seafloor patterns. Furthermore, grounding zone wedge B partly covers some sawtooth ridges (Fig. 6b). 

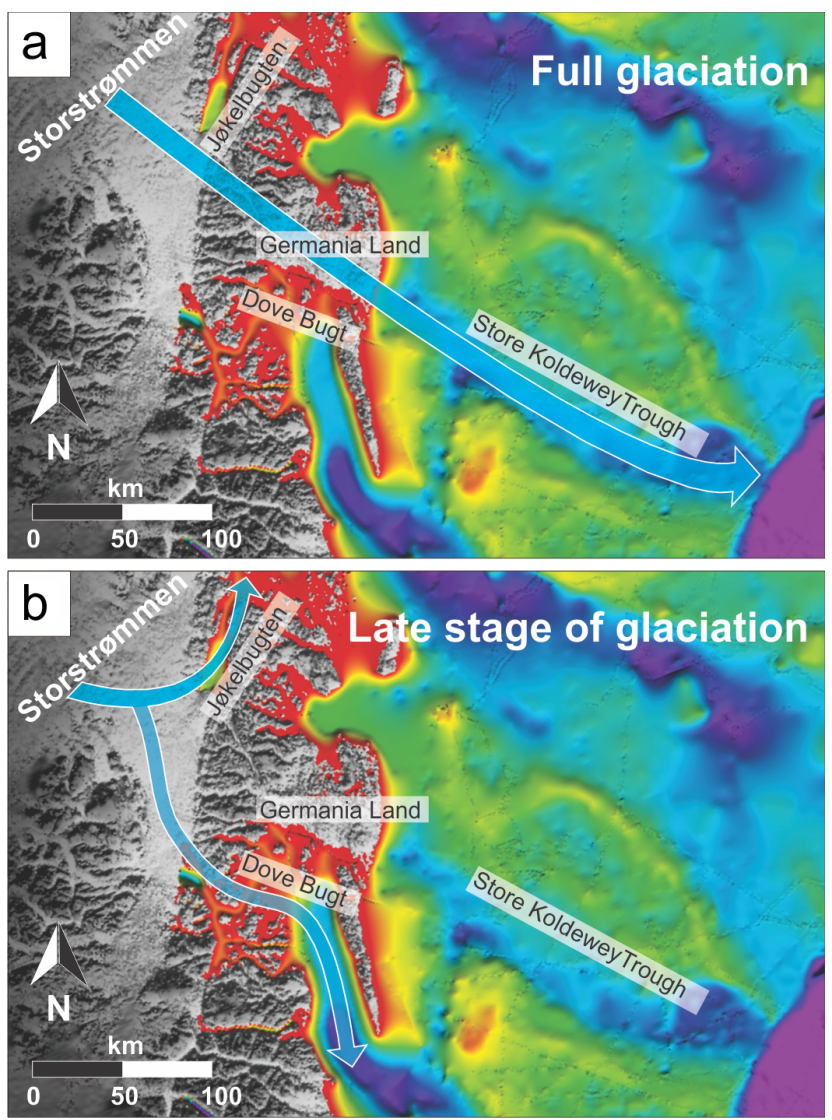

Figure 8. Reconstruction of inferred paleo-ice-flow directions showing (a) paleo-ice-flow unrelated to the underlying topography during full glaciation and (b) ice drainage paths during a late stage of glaciation (bathymetry and topography from IBCAO v.4.0; Jakobsson et al., 2020).

We interpret the sawtooth ridges as recessional moraines that formed by a combination of push and squeeze processes, recording an active ice retreat punctuated by periodic advances. The formation of these distinctive landforms is inferred to be dependent on the topography, where down-ice widening, in this case of the trough, causes increased transverse stress leading to longitudinal crevasses initiating an irregular ice front. Similar sawtooth-like moraines have been observed in, e.g., Norway (Burki et al., 2009; Matthews et al., 1979), the Barents Sea (Hogan et al., 2010; Kurjanski et al., 2019), Iceland (Chandler et al., 2016; Evans et al., 2016) and Arctic Canada (Andrews and Smithson, 1966). The landforms were previously interpreted as rhombohedral ridges by Laberg et al. (2017) in the western part of the data set from the outer trough. However, we find the sawtooth-like morphology incompatible with the geometric ridge networks of rhombohedral ridges based on the ridges' zigzag pattern in plan view (cf. Bennett et al., 1996).

\subsubsection{Straight incisions - channels}

Two straight incisions that are U-shaped in cross section, $150-300 \mathrm{~m}$ wide and with incision depths of $3-10 \mathrm{~m}$ are identified on the northern and southern trough sidewalls (Fig. 4; Table 3). The incisions are oriented parallel to the recessional moraines and continue beyond the extent of the swath bathymetry data set. They cut into the glacial lineations and the acoustically transparent sediments interpreted as basal till. The landforms are interpreted as channels formed during deglaciation and are probably related to erosion by meltwater.

\subsection{Seismostratigraphy}

Two seismostratigraphic units (S1 and S2) are distinguished in the Chirp sub-bottom profiles in Store Koldewey Trough (Fig. 7).

\subsubsection{Unit S1 - glacigenic deposits and/or sedimentary bedrock}

Unit S1 is the lower seismostratigraphic unit, and the base of this unit represents the acoustic basement. The unit has an acoustically transparent to semi-transparent signature and an irregular top reflection with medium to high amplitude and continuity (Fig. 7b).

The unit correlates with lithological facies $5(\mathrm{Dmm})$ in the sediment cores, interpreted as subglacial till, i.e., it includes subglacial deposits. However, the internal reflection shown in Fig. $7 \mathrm{~d}$ can either be interpreted as a bedrock surface visible on the Chirp profile due to a thin layer of till or as an internal reflection within the till. Furthermore, the Chirp profiles and sediment cores confirm that the grounding zone wedges and recessional moraines consists of subglacial till.

\subsubsection{Unit S2 - glacimarine sediments}

Unit S2 is acoustically transparent (Fig. 7). The unit, maximum $2.5 \mathrm{~m}$ thick, occurs only locally either as an infill between the topographic highs or draping the underlying unit S1. It is absent in most of Store Koldewey Trough (e.g., in the outer trough).

Unit S2 is correlated with the lithological facies $4(F l), 3$ $(F l(d)), 2(F m)$ and $1(F m(d))$, and it occurs at all four core sites. Thus, the unit contains glacimarine deposits reflecting a gradual transition from glacier-proximal to distal environments.

\section{Discussion}

\subsection{Maximum ice sheet extent and influence of subglacial topography}

Mega-scale glacial lineations extending almost to grounding zone wedge A in the outer trough (Figs. 5 and 9: Stage 1), to- 


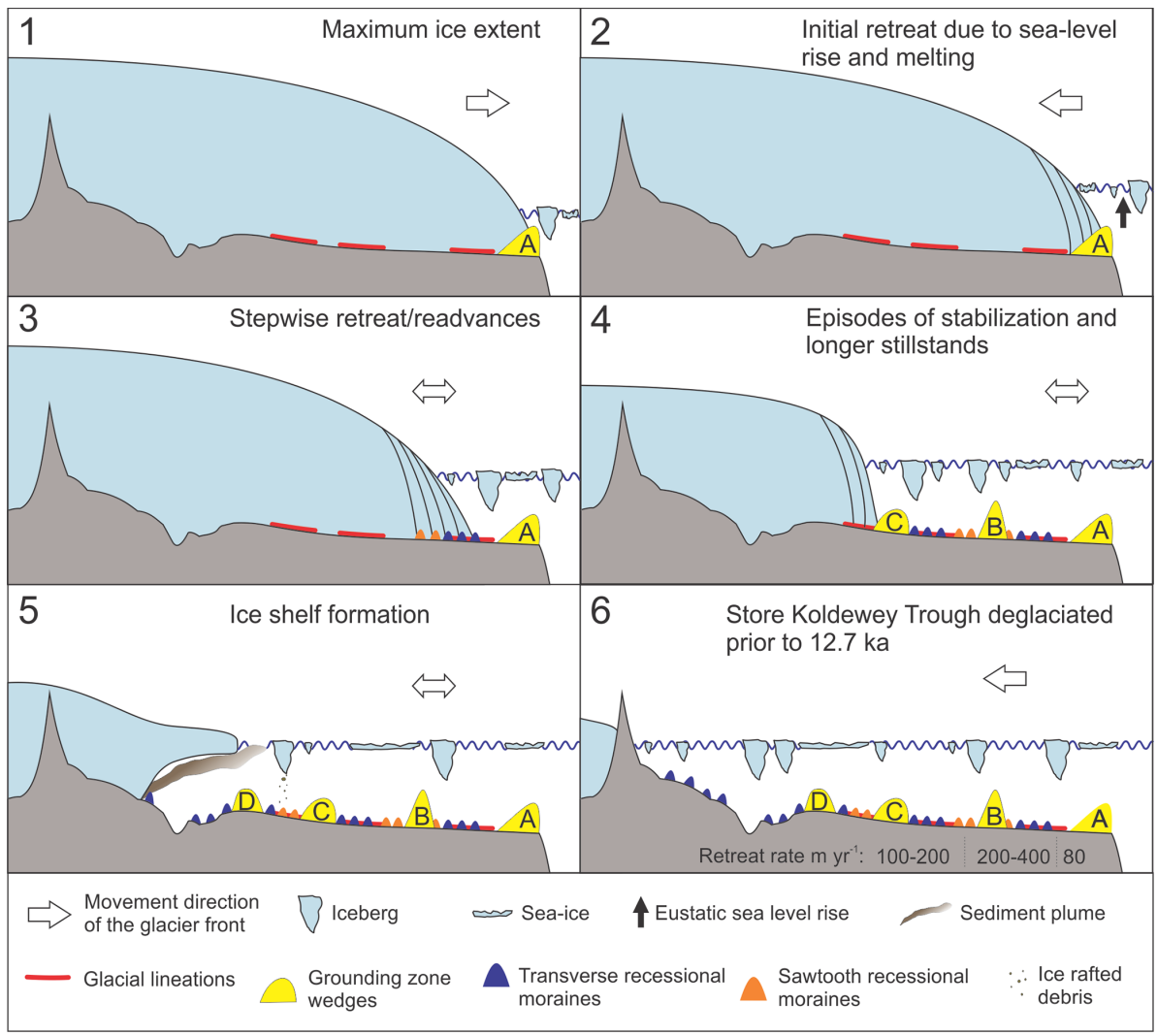

Figure 9. Reconstruction of the ice sheet dynamics in Store Koldewey Trough. Stages 1-6 show the maximum ice extent of the ice stream, as well as the ice stream margin positions during the following deglaciation. Icebergs and sea ice indicate iceberg calving and ice rafting. The deglaciation age in Stage 6 is based on cosmogenic nuclide dating on Store Koldewey Island (Skov et al., 2020).

gether with subglacial debris/basal till in sediment cores from the middle trough, suggest that a grounded, fast-flowing ice stream draining the northeastern sector of the GrIS extended to the shelf break in Store Koldewey Trough at maximum ice extent during the last glacial (Fig. 8a). The absence of a detectable sediment drape in the outer trough (Fig. 7) as well as good preservation of glacial landforms in the outer trough indicates that the identified landforms formed during the LGM and the subsequent deglaciation, as proposed by Laberg et al. (2017).

The shelf-break-terminating ice stream in Store Koldewey Trough is consistent with reconstructions of shelf-breakterminating glaciers during the LGM elsewhere on the NE Greenland Margin, i.e., ranging from our study area in the south to the Westwind Trough at $80.5^{\circ} \mathrm{N}$ in the north (Arndt et al., 2015, 2017; Laberg et al., 2017; Winkelmann et al., 2010) (Fig. 1a). If the maximum glacier extent on the margin occurred synchronously, this implies that an ice sheet front covered a minimum length of $680 \mathrm{~km}$ along the outer shelf.

Stein et al. (1996) presented a chronology of the deposition of terrigenous, coarse-grained material along the continental slope off NE Greenland, suggesting that the maximum late Weichselian ice extent occurred at about 24-19 ka cal BP.
Radiocarbon dates from the Greenland Basin indicate that mass-wasting activity in a channel system on the upper continental slope took place predominantly under full glacial and deglacial conditions and that this had ceased after about $14.7 \mathrm{ka}$ cal BP, leaving the channels largely inactive (Ó Cofaigh et al., 2004). Thus, from the data available, the outer parts of Store Koldewey Trough may have been ice covered in the period from $\sim 24-14.7 \mathrm{kacal} \mathrm{BP}$.

We propose that the Store Koldewey Trough was filled by grounded ice masses deriving from the area presently covered by the Storstrømmen ice stream (Fig. 8a). Paleo-ice sheet models have calculated that the ice covering Germania Land during LGM reached $1000-1500 \mathrm{~m}$ ice thickness (Fleming and Lambeck, 2004; Heinemann et al., 2014). This implies that the northeastern sector of the GrIS likely reached a thickness allowing the ice stream to flow across the underlying topography, including the mountain range with 500 $900 \mathrm{~m}$ high peaks between present-day Storstrømmen and Germania Land. Such "pure" ice streams (Bentley, 1987; Stokes and Clark, 1999), flowing unrelated to topography, are documented from the contemporary Siple Coast ice streams of West Antarctica. Moreover, the disregard for topography appears to be a characteristic of both the paleo- and contem- 
porary NEGIS (Fahnestock et al., 1993; Sachau et al., 2018) (Fig. 1a), as well as for paleo-ice stream within the Laurentide Ice Sheet and Fennoscandian Ice Sheet (e.g., Margold et al., 2015; Ó Cofaigh et al., 2010; Punkari, 1997).

An alternative interpretation is that Store Koldewey Trough had a much smaller drainage basin, limited to Germania Land, as proposed by Arndt et al. (2015). However, based on our data, including the observations of mega-scale glacial lineations, recessional moraines and grounding zone wedges, and the estimates from Fleming and Lambeck (2004) and Heinemann et al. (2014), we favor the interpretation that the Storstrømmen ice stream sourced Store Koldewey Trough during full glacial conditions, based purely on the volume of ice needed to fill a trough of this dimension. Germania Land covers an area of $\sim 2500 \mathrm{~km}^{2}$, and if the ice thickness here reached 1000-1500 $\mathrm{m}$ during LGM (Fleming and Lambeck, 2004; Heinemann et al., 2014), the total ice volume must have been $2500-3750 \mathrm{~km}^{3}$. Store Koldewey Trough covers an area of $\sim 9000 \mathrm{~km}^{2}$, and the present-day water depth at the shelf break is $>400 \mathrm{~m}$. Thus, the volume needed to fill the trough exceeds the ice volume estimated for Germania Land, and a local drainage basin from there is therefore unlikely.

\subsection{Ice stream dynamics during deglaciation}

The complex glacial landform assemblage in Store Koldewey Trough, comprising transverse wedge and ridge systems, reflects to a large degree the dynamic retreat of the ice margin during the deglaciation. The types of landforms and their spatial distributions can be attributed to the overall seafloor topography of the trough, with a seaward dipping bed slope, supplemented by local pinning points related to trough shallowing and/or narrowing. The resulting deglacial dynamics were characterized by several periods of stabilization and readvances of the grounding line in Store Koldewey Trough during overall retreat. In contrast, many paleo-ice streams on other glaciated continental shelves with landward dipping beds have experienced a liftoff from the seafloor and an initial rapid retreat due to sea-level rise, e.g., Norske Trough (Arndt et al., 2017), Amundsen Sea in West Antarctica (Smith et al., 2011) and NW Fennoscandian Ice Sheet (Rydningen et al., 2013) (see Fig. 9: Stage 2).

The retreat landforms of various morphologies mark different retreat styles and periods of grounding line stabilization during retreat (Fig. 9: Stage 3 and 4). While the spatial distribution of the moraine ridges indicates a stepwise retreat with several episodes of relatively short grounding line stabilizations, the presence of four large grounding zone wedges indicates that the glacier also grounded for a longer time during the deglaciation, allowing for larger wedges to form (Dowdeswell et al., 2008; Ó Cofaigh et al., 2008). Because the formation of grounding zone wedges and recessional moraines require a grounded ice stream/glacier mar- gin, we exclude a rapid/continuous retreat by ice stream flotation.

The formation of grounding zone wedges typically requires a stabilization of the ice margin for decades to centuries (Dowdeswell and Fugelli, 2012) (Fig. 9: Stage 4). This period can be estimated when sediment flux across the grounding line and grounding zone wedge volume are known (Howat and Domack, 2003). Grounding zone wedges A to C in Store Koldewey Trough have volumes of approximately 130000,738000 and $150000 \mathrm{~m}^{3} \mathrm{~m}^{-1}$ grounding line width. In the absence of chronology we apply a sediment flux of $10^{2}$ to $10^{3} \mathrm{~m}^{3} \mathrm{~m}^{-1} \mathrm{yr}^{-1}$ to the grounding line, as calculated for other paleo-ice streams in Greenland (Hogan et al., 2012, 2020); the Whillans Ice Stream, West Antarctica (Anandakrishnan et al., 2007); and on the southern Norwegian continental margin (Nygård et al., 2007). Applying these upper and lower sediment flux rates, the periods required for the formation of grounding zone wedges $\mathrm{A}, \mathrm{B}$ and $\mathrm{C}$ are in the range of 130-1300, 740-7400 and 150-1500 years, respectively. The lower flux rate, resulting in an order of magnitude longer formation time, seems less likely given the tight time frame available for retreat across the shelf $(\sim 14.7-12.7 \mathrm{ka}$; Ó Cofaigh et al., 2004; Skov et al., 2020).

The recessional moraines are generally 1 to 3 orders of magnitude smaller than the grounding zone wedges. Accumulations of retreat moraines have repeatedly been referred to as "annual moraines" correlated with annual cycles including winter advances and summer retreats during the overall deglaciation (Baeten et al., 2010; Boulton, 1986; Kempf et al., 2013; Ottesen and Dowdeswell, 2006) (Fig. 9: Stage 3). While annual formation of moraines can be studied in situ in, e.g., Svalbard (Flink et al., 2015; Ottesen and Dowdeswell, 2006), the interpretation of a series of evenly spaced recessional moraines as annual features in the paleo-record is debated (e.g., Chandler et al., 2020). However, assuming that accumulations of retreat moraines reflect annual moraines, we propose the following deglaciation velocities in the study area: following the formation of grounding zone wedge $A$ at the shelf edge, the grounding line (1) retreated with an average of $80 \mathrm{~m} \mathrm{yr}^{-1}$, (2) readvanced and (3) retreated again, accelerating to $200-400 \mathrm{~m} \mathrm{yr}^{-1}$ in the outer trough (Fig. 9: Stage 6). By the time the ice margin reached mid-trough, the spacing of individual moraines indicates a reduced recession of $100-200 \mathrm{~m} \mathrm{yr}^{-1}$. Although estimates on sediment flux and deglacial rates are presented here, we recognize that there are uncertainties in our calculations. Therefore, more precise calculations remain to be defined from other data than ours.

The lithological sequence starting with a basal till overlain by glacimarine deposits suggests the transition from subglacial to an ice-proximal setting and, subsequently, to a more ice-distal environment dominated by suspension settling and various degrees of ice rafting. The deglacial lithofacies (3 and 4) reflect different depositional environments (Table 2): whereas the influence from meltwater was stronger during the deposition of facies 4 , the supply of IRD was 
higher during the deposition of facies 3. The lack of IRD in an ice-proximal setting may have several explanations: (i) the time of deposition may represent a period with an extensive sea-ice cover preventing melt-out of debris in the area (Jennings and Weiner, 1996; Moon et al., 2015; Vorren and Plassen, 2002), (ii) a high flux of sediment-laden glacial meltwater masks the amount of IRD (Boulton, 1990), or (iii) the sediments may be deposited in a sub-shelf environment far enough from the grounding line to be unaffected by mass flows and rain-out of basal debris at the grounding line (Domack and Harris, 1998; Reilly et al., 2019; Smith et al., 2017).

We note that facies 4 , characterized by lamination and the absence of clasts, occurs exclusively in the two cores in the inner trough. Given that the coring sites are located within depressions, it could be assumed that the ice detached from the ground, leading to sub-ice shelf environments where deposition was dominated by suspension settling. Trough narrowing towards the coast could possibly have contributed to an increase in lateral drag and subsequent reduction in extensional stress as the ice front retreated to the innermost trough area, resulting in a more stabilized ice front (grounded) and ice-shelf formation (Fig. 9: Stage 5). Thus, facies 4 was deposited in a similar setting as described by Reilly et al. (2019) for the Petermann Glacier in NW Greenland, where an IRDfree depositional environment beneath a floating ice tongue was followed by an increase in IRD concentrations as the ice tongue retreated from the site.

\subsection{Postglacial development}

During the late phase of the deglaciation, the flow path of the ice stream became controlled by the topography on Store Koldewey Island and Germania Land; i.e., it was directed into Jøkelbugten to the north and Dove Bugt (Dove Bay) in the south (Figs. 8b and 9: Stage 6). This terminated the supply of suspended sediments and icebergs from the Storstrømmen area to Store Koldewey Trough. The generally thin and patchy occurrence of seismostratigraphic unit S2 (correlating to facies $1-4$; Fig. 7) could be due to a change in ice configuration in the west, with ice masses eventually being routed north- and southwards, resulting in a decrease in sediment supply to the trough. More specifically, the absence of a detectable post-glacial sediment cover in the outer trough may be a result of ocean current winnowing from the southwardflowing East Greenland Current, leading to non-preservation of fine-grained sediments here.

Postglacial sedimentary processes in the trough are interpreted to comprise hemipelagic deposition of terrigenous material from sea ice transported across the Arctic Ocean within the Transpolar Drift, rafting by sea ice formed along the NE Greenland coast, rainout from icebergs and meltwater plumes released from regional marine-terminating outlet glaciers north of the study area (e.g., $79^{\circ}$ Glacier and Zachariae Isstrøm), and winnowing on the surrounding banks.

The low IRD content in facies 2 is probably due to multiple factors: (i) ice fronts retreated on land, and (ii) material entrapped in icebergs calving off from marine-terminating glaciers probably melted out rapidly and icebergs only occasionally reached the continental shelf. This could correlate to the Holocene thermal maximum (ca. 8-5 ka) when temperatures in NE Greenland were higher than at present (e.g., Dahl-Jensen et al., 1998; Klug et al., 2009), causing the Storstrømmen ice margin to retreat behind its present ice extent (Bennike and Weidick, 2001; Weidick et al., 1996). Furthermore, sea-ice formation in the Arctic Ocean and on the NE Greenland shelf was reduced during that period (Koç et al., 1993; Funder et al., 2011b; Müller et al., 2012; Werner et al., 2016). The increasing input of IRD towards the top of the sediment cores (Fig. 2) is attributed to the subsequent regional climatic cooling. This climate deterioration, referred to as the neoglaciation (ca. $5 \mathrm{ka}$ - Little Ice Age), led to glacier expansion with enhanced iceberg rafting and increased sea-ice extent on the East Greenland shelf (Klug et al., 2009; Müller et al., 2012).

\section{Conclusions}

- New and previously published swath bathymetry data (Laberg et al., 2017), integrated with high-resolution seismic data and sediment gravity cores, provide new information about the dynamics of the northeastern sector of the Greenland Ice Sheet, as well as about glacial and postglacial sedimentary environments.

- The lithostratigraphy in Store Koldewey Trough includes subglacial till, covered with an up to $2.5 \mathrm{~m}$ thick drape of glacimarine sediments, with the latter reflecting the transitions from sub-ice stream to glacierproximal and glacier-distal deposits.

- The ice stream draining through Store Koldewey Trough probably originated from the area presently covered with the Storstrømmen ice stream. It reached a thickness exceeding the height of the mountains on Store Koldewey Island and Germania Land, leading to ice flow independent of the subglacial topography during full glacial conditions and an early phase of the deglaciation.

- Grounding zone wedges and various types of recessional moraines (transverse and sawtooth recessional moraines) within the trough provide evidence that multiple halts and/or readvances interrupted the deglaciation. The formation of the grounding zone wedges probably took at least 130 years. Assuming that the recessional moraines were annually formed, the distances between the moraines indicate that the grounding line lo- 
cally retreated between 80 and $400 \mathrm{~m} \mathrm{yr}^{-1}$ during the deglaciation.

- The complex geomorphology in Store Koldewey Trough is attributed to the trough shallowing and narrowing towards the coast, affecting the formation of grounding zone wedges.

- Ice sheet thinning during a late stage of the deglaciation led to topographically controlled ice flow, leading to diversion of the ice stream to Jøkelbugten and Dove Bugt, and, in consequence, terminating sediment supply to Store Koldewey Trough.

Data availability. Data requests can be addressed to the corresponding author. The access will depend on Greenlandic regulations valid at the time of the request.

Author contributions. The idea of the study developed from repeated discussions among the authors of this study and the opportunity to participate in multiple scientific cruises to the study area. ILO, JS and TAR collected the new data during the TUNU VII cruise. The geophysical and lithological data were interpreted by ILO in collaboration with MF, JSL and TAR. ILO conducted sample preparation and analyses of sediment data with help from $\mathrm{KH}$. ILO wrote the manuscript with contributions from all authors.

Competing interests. The authors declare that they have no conflict of interest.

Acknowledgements. We thank the captains, crews and participants on board the 2013, 2015 and 2017 cruises with RV Helmer Hanssen, arranged by the TUNU program led by Jørgen Schou Christansen, UiT The Arctic University of Norway. Furthermore, we acknowledge our cruise engineers Bjørn Runar Olsen and Steinar Iversen, as well as our laboratory engineers Trine Dahl, Ingvild Hald and Karina Monsen for their technical support during and after the cruises. Finally, we would like to thank Editor Chris Stokes and our two referees, including Sarah Greenwood, for their thorough and critical reviews, as well as for their constructive comments that improved the manuscript.

Review statement. This paper was edited by Chris R. Stokes and reviewed by Sarah Greenwood and one anonymous referee.

\section{References}

Aagaard, K. and Coachman, L. K.: The East Greenland Current North of Denmark Strait?: Part I, Arctic, 21, 181-200, 1968.

AMAP: Summary - The Greenland Ice Sheet in a Changing Climate: Snow, Water, Ice and Permafrost in the Arctic (SWIPA)
2009, Arctic Monitoring and Assessment Programme (AMAP), Oslo, 22 pp., 2009.

Anandakrishnan, S., Catania, G. A., Alley, R. B., and Horgan, H. J.: Discovery of till deposition at the grounding line of Whillans Ice Stream, Science, 315, 1835-1838, https://doi.org/10.1126/science.1138393, 2007.

Andreassen, K., Winsborrow, M. C. M., Bjarnadóttir, L. R., and Rüther, D. C.: Ice stream retreat dynamics inferred from an assemblage of landforms in the northern Barents Sea, Quaternary Sci. Rev., 92, 246-257, https://doi.org/10.1016/j.quascirev.2013.09.015, 2014.

Andrews, J. T. and Smithson, B. B.: Till fabrics of the cross-valley moraines of North-Central Baffin Island, Nortwest Territories, Canada, GSA Bull., 77, 271-290, 1966.

Andrews, J. T., Cooper, T. A., Jennings, A. E., Stein, A. B., and Erlenkeuser, H.: Late Quaternary iceberg-rafted detritus events on the Denmark Strait-Southeast Greenland continental slope $\left(\sim 65^{\circ} \mathrm{N}\right)$ : Related to North Atlantic Heinrich events?, Mar. Geol., 149, 211-228, https://doi.org/10.1016/S00253227(98)00029-2, 1998

Andrews, J. T., Domack, E. W., Cunningham, W. L., Leventer, A., Licht, K. J., Jull, A. J. T., DeMaster, D. J., and Jennings, A. E.: Problems and possible solutions concerning radiocarbon dating of surface marine sediments, Ross Sea, Antarctica, Quaternary Res., 52, 206-216, https://doi.org/10.1006/qres.1999.2047, 1999.

Andrews, J. T., Stein, R., Moros, M., and Perner, K.: Late Quaternary changes in sediment composition on the NE Greenland margin $\left(\sim 73^{\circ} \mathrm{N}\right)$ with a focus on the fjords and shelf, Boreas, 45, 381-397, https://doi.org/10.1111/bor.12169, 2016.

Arndt, J. E.: Marine geomorphological record of Ice Sheet development in East Greenland since the Last Glacial Maximum, J. Quaternary Sci., 33, 853-864, https://doi.org/10.1002/jqs.3065, 2018 .

Arndt, J. E., Jokat, W., Dorschel, B., Myklebust, R., Dowdeswell, J. A., and Evans, J.: A new bathymetry of the Northeast Greenland continental shelf: Constraints on glacial and other processes, Geochem. Geophy. Geosy., 16, 3733-3753, https://doi.org/10.1002/2015GC005931, 2015.

Arndt, J. E., Jokat, W., and Dorschel, B.: The last glaciation and deglaciation of the Northeast Greenland continental shelf revealed by hydro-acoustic data, Quaternary Sci. Rev., 160, 45-56, https://doi.org/10.1016/j.quascirev.2017.01.018, 2017.

Baeten, N. J., Forwick, M., Vogt, C., and Vorren, T. O.: Late Weichselian and Holocene sedimentary environments and glacial activity in Billefjorden, Svalbard, Geol. Soc. Spec. Publ., 344, 207 223, https://doi.org/10.1144/SP344.15, 2010.

Bamber, J. L., Ekholm, S., and Krabill, W. B.: A new, highresolution digital elevation model of Greenland fully validated with airborne laser altimeter data, J. Geophys. Res., 106, 67336745, 2001.

Bamber, J. L., Riva, R. E. M., Vermeersen, B. L. A. and Lebrocq, A. M.: Reassessment of the Potential of the West Antarctic Ice Sheet, Science, 324, 901-904, https://doi.org/10.1126/science.1169335, 2009.

Batchelor, C. L. and Dowdeswell, J. A.: The physiography of High Arctic cross-shelf troughs, Quaternary Sci. Rev., 92, 6896, https://doi.org/10.1016/j.quascirev.2013.05.025, 2014. 
Bendtsen, J., Mortensen, J., Lennert, K., Ehn, J. K., Boone, W., Galindo, V., Hu, Y. B., Dmitrenko, I. A., Kirillov, S. A., Kjeldsen, K. K., Kristoffersen, Y., Barber, D. G., and Rysgaard, S.: Sea ice breakup and marine melt of a retreating tidewater outlet glacier in northeast Greenland $\left(81^{\circ} \mathrm{N}\right)$, Sci. Rep., 7, 1-11, https://doi.org/10.1038/s41598-017-05089-3, 2017.

Bennett, M. R., Hambrey, M. J., Huddart, D., and Ghienne, J. F.: The formation of a geometrical ridge network by the surge-type glacier Kongsvegen, Svalbard, J. Quaternary Sci., 11, 437-449, https://doi.org/10.1002/(sici)10991417(199611/12)11:6<437::aid-jqs269>3.3.co;2-a, 1996.

Bennike, O. and Weidick, A.: Late Quaternary history around Nioghalvfjerdsfjorden and Jøkelbugten, North-East Greenland, Boreas, 30, 205-227, https://doi.org/10.1111/j.15023885.2001.tb01223.x, 2001.

Bennike, O., Björck, S., and Lambeck, K.: Estimates of South Greenland late-glacial ice limits from a new relative sea level curve, Earth Planet. Sc. Lett., 197, 171-186, https://doi.org/10.1016/S0012-821X(02)00478-8, 2002.

Bentley, C. R.: Antarctic ice streams: a review, J. Geophys. Res., 92, 8843-8858, 1987.

Bjarnadóttir, L. R., Rüther, D. C., Winsborrow, M. C. M., and Andreassen, K.: Grounding-line dynamics during the last deglaciation of Kveithola, W Barents Sea, as revealed by seabed geomorphology and shallow seismic stratigraphy, Boreas, 42, 84-107, https://doi.org/10.1111/j.1502-3885.2012.00273.x, 2013.

Blott, S. J. and Pye, K.: GRADISTAT: a grain size distribution and statistics package for the analysis of unconsolidated sediments, Earth. Surf. Proc. Land., 26, 1237-1248, https://doi.org/10.1016/S0167-5648(08)70015-7, 2001.

Boulton, G. S.: Push-moraines and glacier-contact fans in marine and terrestrial environments, Sedimentology, 33, 677-698, https://doi.org/10.1111/j.1365-3091.1986.tb01969.x, 1986.

Boulton, G. S.: Sedimentary and sea level changes during glacial cycles and their control on glacimarine facies architecture, in: Glacimarine environments: Processess and Sediments, edited by: Dowdeswell, J. A. and Scourse, J. D., Geological Society Special Publications, 15-52, 1990.

Burki, V., Larsen, E., Fredin, O., and Margreth, A.: The formation of sawtooth moraine ridges in $\mathrm{B} \emptyset$ dalen, western Norway, Geomorphology, 105, 182-192, https://doi.org/10.1016/j.geomorph.2008.06.016, 2009.

Canals, M., Urgeles, R., and Calafat, A. M.: Deep sea-floor evidence of past ice streams off the Antarctic Peninsula, Geology, 28, 31-34, https://doi.org/10.1130/00917613(2000)028<0031:DSEOPI>2.0.CO;2, 2000.

Chandler, B. M. P., Evans, D. J. A., and Roberts, D. H.: Characteristics of recessional moraines at a temperate glacier in SE Iceland: Insights into patterns, rates and drivers of glacier retreat, Quaternary Sci. Rev., 135, 171-205, https://doi.org/10.1016/j.quascirev.2016.01.025, 2016.

Chandler, B. M. P., Chandler, S. J. P., Evans, D. J. A., Ewertowski, M. W., Lovell, H., Roberts, D. H., Schaefer, M., and Tomczyk, A. M.: Sub-annual moraine formation at an active temperate Icelandic glacier, Earth. Surf. Proc. Land., 45, 1622-1643, https://doi.org/10.1002/esp.4835, 2020.

Christiansen, J. S.: The TUNU-programme: euro-arctic marine fishes - diversity and adaption, in: Adaptation and Evolution in
Marine Environments, Vol. 1, From Pole to Pole, edited by: Di Prisco, V. C., Springer, Berlin, Heidelberg, 35-50, 2012.

Clark, C. D.: Mega-scale glacial lineations and cross-cutting iceflow landforms, Earth. Surf. Proc. Land., 18, 1-29, 1993.

Clark, P. U., Dyke, A. S., Shakun, J. D., Carlson, A. E., Clark, J., Wohlfarth, B., Mitrovica, J. X., Hostetler, S. W., and McCabe, A. M.: The Last Glacial Maximum, Science, 325, 710 714, https://doi.org/10.1126/science.1172873, 2009.

Dahl-Jensen, D., Mosegaard, K., Gundestrup, N., Clow, G. D., Johnsen, S. J., Hansen, A. W., and Balling, N.: Past Temperatures Directly from the Greenland Ice Sheet, Science, 282, 268-271, https://doi.org/10.1126/science.282.5387.268, 1998.

Domack, E. W. and Harris, P. T.: A new depositional model for ice shelves, based upon sediment cores from the Ross Sea and the Mac. Robertson shelf, Antarctica, Ann. Glaciol., 27, 281-284, https://doi.org/10.3189/1998aog27-1-281-284, 1998.

Domack, E. W., Jacobson, E. A., Shipp, S., and Anderson, J. B.: Late Pleistocene - Holocene retreat of the West Antarctic IceSheet system in the Ross Sea: Part 2 - Sedimentologic and stratigraphic signature, GSA Bull., 111, 1517-1536, 1999.

Dowdeswell, J. A. and Fugelli, E. M. G.: The seismic architecture and geometry of grounding-zone wedges formed at the marine margins of past ice sheets, Geol. Soc. Am. Bull., 124, 1750 1761, https://doi.org/10.1130/B30628.1, 2012.

Dowdeswell, J. A., Uenzelmann-Neben, G., Whittington, R. J., and Marienfeld, P.: The Late Quaternary sedimentary record in Scoresby Sund, East Greenland, Boreas, 23, 294-310, https://doi.org/10.1111/j.1502-3885.1994.tb00602.x, 1994.

Dowdeswell, J. A., Ottesen, D., Evans, J., Cofaigh, C. Ó., and Anderson, J. B.: Submarine glacial landforms and rates of ice-stream collapse, Geology, 36, 819-822, https://doi.org/10.1130/G24808A.1, 2008.

Dowdeswell, J. A., Hogan, K. A., Ó Cofaigh, C., Fugelli, E. M. G., Evans, J., and Noormets, R.: Late Quaternary ice flow in a West Greenland fjord and cross-shelf trough system: Submarine landforms from Rink Isbrae to Uummannaq shelf and slope, Quaternary Sci. Rev., 92, 292-309, https://doi.org/10.1016/j.quascirev.2013.09.007, 2014

Evans, D. J. A., Phillips, E. R., Hiemstra, J. F., and Auton, C. A.: Subglacial till: Formation, sedimentary characteristics and classification, Earth-Sci. Rev., 78, 115-176, https://doi.org/10.1016/j.earscirev.2006.04.001, 2006.

Evans, D. J. A., Ewertowski, M., and Orton, C.: Fláajökull (north lobe), Iceland: active temperate piedmont lobe glacial landsystem, J. Maps, 12, 777-789, https://doi.org/10.1080/17445647.2015.1073185, 2016.

Evans, J., Dowdeswell, J. A., Grobe, H., Niessen, F., Stein, R., Hubberten, H.-W., and Whittington, R. J.: Late Quaternary sedimentation in Kejser Franz Joseph Fjord and the continental margin of East Greenland, Geol. Soc. Spec. Publ., 203, 149-179, https://doi.org/10.1144/GSL.SP.2002.203.01.09, 2002.

Evans, J., Ó Cofaigh, C., Dowdeswell, J. A., and Wadhams, P.: Marine geophysical evidence for former expansion and flow of the Greenland Ice Sheet across the north-east Greenland continental shelf, J. Quaternary Sci., 24, 279-293, https://doi.org/10.1002/jqs.1231, 2009.

Fahnestock, M., Bindschadler, R., Kwok, R., and Jezek, K.: Greenland Ice Sheet surface properties and ice dynam- 
ics from ERS-1 SAR imagery, Science, 262, 1530-1534, https://doi.org/10.1126/science.262.5139.1530, 1993.

Fleming, K. and Lambeck, K.: Constraints on the Greenland Ice Sheet since the Last Glacial Maximum from sea-level observations and glacial-rebound models, Quaternary Sci. Rev., 23, 1053-1077, https://doi.org/10.1016/j.quascirev.2003.11.001, 2004.

Flink, A. E., Noormets, R., Kirchner, N., Benn, D. I., Luckman, A., and Lovell, H.: The evolution of a submarine landform record following recent and multiple surges of Tunabreen glacier, Svalbard, Quaternary Sci. Rev., 108, 37-50, https://doi.org/10.1016/j.quascirev.2014.11.006, 2015.

Funder, S., Goosse, H., Jepsen, H., Kaas, E., Kjær, K. H., Korsgaard, N. J., Larsen, N. K., Linderson, H., Lyså, A., Möller, P., Olsen, J., and Willerslev, E.: A 10,000-Year Record of Arctic Ocean Sea-Ice Variability - View from the Beach, Science, 333, 747-750, https://doi.org/10.2307/j.ctv9zcj2n.53, 2011 a.

Funder, S., Kjeldsen, K. K., Kjær, K. H., and Ó Cofaigh, C.: The Greenland Ice Sheet During the Past 300,000 Years: A Review, Developments in Quaternary Sciences, 15, 699-713, https://doi.org/10.1016/B978-0-444-53447-7.00050-7, $2011 \mathrm{~b}$.

Fürst, J. J., Goelzer, H., and Huybrechts, P.: Ice-dynamic projections of the Greenland ice sheet in response to atmospheric and oceanic warming, The Cryosphere, 9, 1039-1062, https://doi.org/10.5194/tc-9-1039-2015, 2015.

Heaton, T. J., Köhler, P., Butzin, M., Bard, E., Reimer, R. W., Austin, W. E. N., Ramsey, C. B., Grootes, P. M., Hughen, K. A., Kromer, B., Reimer, P. J., Adkins, J., Burke, A., Cook, M. S., Olsen, J., and Skinner, L. C.: Marine20- the marine radiocarbon age calibration curve (0-55000 cal BP), Radiocarbon, 62, 779820, https://doi.org/10.1017/RDC.2020.68, 2020.

Heinemann, M., Timmermann, A., Elison Timm, O., Saito, F., and Abe-Ouchi, A.: Deglacial ice sheet meltdown: orbital pacemaking and $\mathrm{CO}_{2}$ effects, Clim. Past, 10, 1567-1579, https://doi.org/10.5194/cp-10-1567-2014, 2014.

Hogan, K. A., Dowdeswell, J. A., Noormets, R., Evans, J., and Ó Cofaigh, C.: Evidence for full-glacial flow and retreat of the Late Weichselian Ice Sheet from the waters around Kong Karls Land, eastern Svalbard, Quaternary Sci. Rev., 29, 3563-3582, https://doi.org/10.1016/j.quascirev.2010.05.026, 2010.

Hogan, K. A., Dix, J. K., Lloyd, J. M., Long, A. J., and Cotterill, C. J.: Seismic stratigraphy records the deglacial history of Jakobshavn Isbræ, West Greenland, J. Quaternary Sci., 26, 757-766, https://doi.org/10.1002/jqs.1500, 2011.

Hogan, K. A., Dowdeswell, J. A., and Ó Cofaigh, C.: Glacimarine sedimentary processes and depositional environments in an embayment fed by West Greenland ice streams, Mar. Geol., 311314, 1-16, https://doi.org/10.1016/j.margeo.2012.04.006, 2012.

Hogan, K. A., Colm, O., Jennings, A. E., Dowdeswell, J. A., and Hiemstra, J. F.: Deglaciation of a major palaeo-ice stream in Disko Trough, West Greenland, Quaternary Sci. Rev., 147, 5-26, https://doi.org/10.1016/j.quascirev.2016.01.018, 2016.

Hogan, K. A., Jakobsson, M., Mayer, L., Reilly, B. T., Jennings, A. E., Stoner, J. S., Nielsen, T., Andresen, K. J., Nørmark, E., Heirman, K. A., Kamla, E., Jerram, K., Stranne, C., and Mix, A.: Glacial sedimentation, fluxes and erosion rates associated with ice retreat in Petermann Fjord and Nares Strait, north-west Greenland, The Cryosphere, 14, 261-286, https://doi.org/10.5194/tc-14-261-2020, 2020.
Hopkins, T. S.: The GIN Sea-A synthesis of its physical oceanography and literature review 1972-1985, Earth-Sci. Rev., 30, 175318, https://doi.org/10.1016/0012-8252(91)90001-V, 1991.

Howat, I. and Domack, E.: Reconstructions of western Ross Sea palaeo-ice-stream grounding zones from high-resolution acoustic stratigraphy, Boreas, 32, 56-75, https://doi.org/10.1080/03009480310001038, 2003.

Hubberten, H., Grobe, H., Jokat, W., Melles, M., Niessen, F., and Stein, R.: Glacial history of East Greenland explored, Eos Trans. AGU, 76, 353-356, 1995.

IPCC: IPCC special report on the impacts of global warming of $1.5^{\circ} \mathrm{C}$ - Summary for policy makers, available at: http://www. ipcc.ch/report/sr15/, last access: 28 October 2018.

Jakobsson, M., Anderson, J. B., Nitsche, F. O., Gyllencreutz, R., Kirshner, A. E., Kirchner, N., O'Regan, M., Mohammad, R., and Eriksson, B.: Ice sheet retreat dynamics inferred from glacial morphology of the central Pine Island Bay Trough, West Antarctica, Quaternary Sci. Rev., 38, 1-10, https://doi.org/10.1016/j.quascirev.2011.12.017, 2012a.

Jakobsson, M., Mayer, L., Coakley, B., Dowdeswell, J. A., Forbes, S., Fridman, B., Hodnesdal, H., Noormets, R., Pedersen, R., Rebesco, M., Schenke, H. W., Zarayskaya, Y., Accettella, D., Armstrong, A., Anderson, R. M., Bienhoff, P., Camerlenghi, A., Church, I., Edwards, M., Gardner, J. V., Hall, J. K., Hell, B., Hestvik, O., Kristoffersen, Y., Marcussen, C., Mohammad, R., Mosher, D., Nghiem, S. V., Pedrosa, M. T., Travaglini, P. G., and Weatherall, P.: The International Bathymetric Chart of the Arctic Ocean (IBCAO) Version 3.0, Geophys. Res. Lett., 39, 1-6, https://doi.org/10.1029/2012GL052219, 2012b.

Jakobsson, M., Mayer, L. A., Bringensparr, C., Castro, C. F., Mohammad, R., Johnson, P., Ketter, T., Accettella, D., Amblas, D., An, L., Arndt, J. E., Canals, M., Casamor, J. L., Chauché, N., Coakley, B., Danielson, S., Demarte, M., Dickson, M. L., Dorschel, B., Dowdeswell, J. A., Dreutter, S., Fremand, A. C., Gallant, D., Hall, J. K., Hehemann, L., Hodnesdal, H., Hong, J., Ivaldi, R., Kane, E., Klaucke, I., Krawczyk, D. W., Kristoffersen, Y., Kuipers, B. R., Millan, R., Masetti, G., Morlighem, M., Noormets, R., Prescott, M. M., Rebesco, M., Rignot, E., Semiletov, I., Tate, A. J., Travaglini, P., Velicogna, I., Weatherall, P., Weinrebe, W., Willis, J. K., Wood, M., Zarayskaya, Y., Zhang, T., Zimmermann, M., and Zinglersen, K. B.: The International Bathymetric Chart of the Arctic Ocean Version 4.0, Sci. Data, 7, 176, https://doi.org/10.1038/s41597-020-0520-9, 2020.

Jennings, A. E. and Weiner, N. J.: Environmental change in eastern Greenland during the last 1300 years?: evidence from foraminifera and lithofacies in Nansen Fjord, $68^{\circ} \mathrm{N}$, Holocene, 6, 179-191, 1996.

Joughin, I. R., Fahnestock, M. A., and Bamber, J. L.: Ice flow in the northeast Greenland ice stream, Ann. Glaciol., 31, 141-146, https://doi.org/10.1016/j.radphyschem.2012.12.021, 2000.

Kempf, P., Forwick, M., Laberg, J. S., and Vorren, T. O.: Late Weichselian and Holocene sedimentary palaeoenvironment and glacial activity in the high-arctic van Keulenfjorden, Spitsbergen, Holocene, 23, 1607-1618, https://doi.org/10.1177/0959683613499055, 2013.

Khan, S. A., Kjær, K. H., Bevis, M., Bamber, J. L., Wahr, J., Kjeldsen, K. K., Bjørk, A. A., Korsgaard, N. J., Stearns, L. A., Van Den Broeke, M. R., Liu, L., Larsen, N. K., and Muresan, I. S.: Sustained mass loss of the northeast Greenland ice sheet trig- 
gered by regional warming, Nat. Clim. Change, 4, 292-299, https://doi.org/10.1038/nclimate2161, 2014.

King, E. C., Hindmarsh, R. C. A., and Stokes, C. R.: Formation of mega-scale glacial lineations observed beneath a West Antarctic ice stream, Nat. Geosci., 2, 585-588, https://doi.org/10.1038/ngeo581, 2009.

Klages, J. P., Kuhn, G., Hillenbrand, C. D., Graham, A. G. C., Smith, J. A., Larter, R. D., and Gohl, K.: First geomorphological record and glacial history of an inter-ice stream ridge on the West Antarctic continental shelf, Quaternary Sci. Rev., 61, 4761, https://doi.org/10.1016/j.quascirev.2012.11.007, 2013.

Klug, M., Bennike, O., and Wagner, B.: Repeated shortterm bioproductivity changes in a coastal lake on Store Koldewey, northeast Greenland: An indicator of varying sea-ice coverage?, Holocene, 19, 653-663, https://doi.org/10.1177/0959683609104040, 2009.

Koç, N., Jansen, E., and Haflidason, H.: Paleoceanographic reconstructions of surface ocean conditions in the Greenland, Iceland and Norwegian Seas through the last 14 ka based on diatoms, Quaternary Sci. Rev., 12, 115-140, 1993.

Kurjanski, B., Rea, B. R., Spagnolo, M., Winsborrow, M., Cornwell, D. G., Andreassen, K., and Howell, J.: Morphological evidence for marine ice stream shutdown, central Barents Sea, Mar. Geol., 414, 64-76, https://doi.org/10.1016/j.margeo.2019.05.001, 2019.

Laberg, J. S., Forwick, M., and Husum, K.: New geophysical evidence for a revised maximum position of part of the NE sector of the Greenland ice sheet during the last glacial maximum, Arktos, 3, 3, https://doi.org/10.1007/s41063-017-0029-4, 2017.

Landvik, J. Y.: The last glaciation of Germania Land and adjacent areas, northeast Greenland, J. Quaternary Sci., 9, 81-92, https://doi.org/10.1002/jqs.3390090108, 1994.

Lenton, T. M., Held, H., Kriegler, E., Hall, J. W., Lucht, W., Rahmstorf, S., and Joachim, H.: Tipping elements in the Earth's climate system, P. Natl. Acad. Sci. USA, 105, 1786 -1793, https://doi.org/10.1073/pnas.0705414105, 2008.

Margold, M., Stokes, C. R., and Clark, C. D.: Ice streams in the Laurentide Ice Sheet: Identification, characteristics and comparison to modern ice sheets, Earth-Sci. Rev., 143, 117-146, https://doi.org/10.1016/j.earscirev.2015.01.011, 2015.

Matthews, J. A., Cornish, R., and Shakesby, R. A.: "Saw-Tooth" Moraines in Front of Bødalsbreen, Southern Norway, J. Glaciol., 22, 535-546, https://doi.org/10.3189/s0022143000014519, 1979.

Mayer, C., Schaffer, J., Hattermann, T., Floricioiu, D., Krieger, L., Dodd, P. A., Kanzow, T., Licciulli, C., and Schannwell, C.: Large ice loss variability at Nioghalvfjerdsfjorden Glacier, Northeast-Greenland, Nat. Commun., 9, 1-11, https://doi.org/10.1038/s41467-018-05180-x, 2018.

Moon, T., Joughin, I., and Smith, B.: Seasonal to multiyear variability of glacier surface velocity, terminus position, and sea ice/ice mélange in northwest Greenland, J. Geophys. Res.-Earth, 120, 818-833, https://doi.org/10.1002/2015JF003494, 2015.

Müller, J., Werner, K., Stein, R., Fahl, K., Moros, M., and Jansen, E.: Holocene cooling culminates in sea ice oscillations in Fram Strait, Quaternary Sci. Rev., 47, 1-14, https://doi.org/10.1016/j.quascirev.2012.04.024, 2012.

Munsell Color Company: x-rite: Munsell Soil Color Charts (Year 2000 Revised Washable Edition), 50 pp., 2000.
Nick, F. M., Vieli, A., Andersen, M. L., Joughin, I., Payne, A., Edwards, T. L., Pattyn, F., and Van De Wal, R. S. W.: Future sea-level rise from Greenland's main outlet glaciers in a warming climate, Nature, 497, 235-238, https://doi.org/10.1038/nature12068, 2013.

Nygård, A., Sejrup, H. P., Haflidason, H., Lekens, W. A. H., Clark, C. D., and Bigg, G. R.: Extreme sediment and ice discharge from marine-based ice streams: New evidence from the North Sea, Geology, 35, 395-398, https://doi.org/10.1130/G23364A.1, 2007.

Ó Cofaigh, C. and Dowdeswell, J. A.: Laminated sediments in glacimarine environments: Diagnostic criteria for their interpretation, Quaternary Sci. Rev., 20, 1411-1436, https://doi.org/10.1016/S0277-3791(00)00177-3, 2001.

Ó Cofaigh, C., Dowdeswell, J. A., Evans, J., Kenyon, N. H., Taylor, J., Mienert, J., and Wilken, M.: Timing and significance of glacially influenced mass-wasting in the submarine channels of the Greenland Basin, Mar. Geol., 207, 39-54, https://doi.org/10.1016/j.margeo.2004.02.009, 2004.

Ó Cofaigh, C., Evans, J., Dowdeswell, J. A., and Larter, R. D.: Till characteristics, genesis and transport beneath Antarctic paleo-ice streams, J. Geophys. Res.-Earth, 112, 1-16, https://doi.org/10.1029/2006JF000606, 2007.

Ó Cofaigh, C., Dowdeswell, J. A., Evans, J., and Larter, R. D.: Geological constraints on Antarctic palaeo-ice-stream retreat, Earth. Surf. Proc. Land., 33, 513-525, https://doi.org/10.1002/esp, 2008.

Ó Cofaigh, C., Evans, D. J. A., and Smith, I. R.: Large-scale reorganization and sedimentation of terrestrial ice streams during late Wisconsinan Laurentide Ice Sheet deglaciation, Bull. Geol. Soc. Am., 122, 743-756, https://doi.org/10.1130/B26476.1, 2010.

Ó Cofaigh, C., Dowdeswell, J. A., Jennings, A. E., Hogan, K. A., Kilfeather, A., Hiemstra, J. F., Noormets, R., Evans, J., McCarthy, D. J., Andrews, J. T., Lloyd, J. M., and Moros, M.: An extensive and dynamic ice sheet on the west greenland shelf during the last glacial cycle, Geology, 41, 219-222, https://doi.org/10.1130/G33759.1, 2013.

Ottesen, D. and Dowdeswell, J. A.: Assemblages of submarine landforms produced by tidewater glaciers in Svalbard, J. Geophys. Res.-Earth, 111, 1-16, https://doi.org/10.1029/2005JF000330, 2006.

Ottesen, D. and Dowdeswell, J. A.: An inter-ice-stream glaciated margin: Submarine landforms and a geomorphic model based on marine-geophysical data from Svalbard, Bull. Geol. Soc. Am., 121, 1647-1665, https://doi.org/10.1130/B26467.1, 2009.

Ottesen, D., Dowdeswell, J. A., and Rise, L.: Submarine landforms and the reconstruction of fast-flowing ice streams within a large Quaternary ice sheet: The 2500-km-long Norwegian-Svalbard margin $\left(57^{\circ}-80^{\circ} \mathrm{N}\right)$, Bull. Geol. Soc. Am., 117, 1033-1050, https://doi.org/10.1130/B25577.1, 2005.

Petersen, T. G., Hamann, N. E., and Stemmerik, L.: Tectonosedimentary evolution of the Paleogene succession offshore Northeast Greenland, Mar. Petrol. Geol., 67, 481-497, https://doi.org/10.1016/j.marpetgeo.2015.05.033, 2015.

Prothro, L. O., Simkins, L. M., Majewski, W., and Anderson, J. B.: Glacial retreat patterns and processes determined from integrated sedimentology and geomorphology records, Mar. Geol., 395, 104-119, https://doi.org/10.1016/j.margeo.2017.09.012, 2018.

Punkari, M.: Subglacial processes of the Scandinavian ice sheet in Fennoscandia inferred from flow-parallel fea- 
tures and lithostratigraphy, Sediment. Geol., 111, 263-283, https://doi.org/10.1016/S0037-0738(97)00019-5, 1997.

Reilly, B. T., Stoner, J. S., Mix, A. C., Walczak, M. H., Jennings, A., Jakobsson, M., Dyke, L., Glueder, A., Nicholls, K., Hogan, K. A., Mayer, L. A., Hatfield, R. G., Albert, S., Marcott, S., Fallon, S., and Cheseby, M.: Holocene break-up and reestablishment of the Petermann Ice Tongue, Northwest Greenland, Quaternary Sci. Rev., 218, 322-342, https://doi.org/10.1016/j.quascirev.2019.06.023, 2019.

Rignot, E. and Kanagaratnam, P.: Changes in the velocity structure of the Greenland Ice Sheet, Science, 311, 986-990, https://doi.org/10.1126/science.1121381, 2006.

Rydningen, T. A., Vorren, T. O., Laberg, J. S., and Kolstad, V.: The marine-based NW Fennoscandian ice sheet: Glacial and deglacial dynamics as reconstructed from submarine landforms, Quaternary Sci. Rev., 68, 126-141, https://doi.org/10.1016/j.quascirev.2013.02.013, 2013.

Sachau, T., Bons, P., and Jansen, D.: The dynamics and geometry of pure ice streams: a new numerical approach, in: EGU General Assembly Conference Abstracts, p. 18623, Vienna, Austria, Vol. 20, EGU2018-18623, 2018.

Serreze, M. C. and Francis, J. A.: The arctic amplification debate, Clim. Change, 76, 241-264, https://doi.org/10.1007/s10584005-9017-y, 2006.

Skov, D. S., Andersen, J. L., Olsen, J., Jacobsen, B. H., Knudsen, M. F., Jansen, J. D., Larsen, N. K., and Egholm, D. L.: Constraints from cosmogenic nuclides on the glaciation and erosion history of Dove Bugt, northeast Greenland, Geol. Soc. Am. Bull., 132, 2282-2294, https://doi.org/10.1130/B35410.1, 2020.

Smith, J. A., Hillenbrand, C. D., Kuhn, G., Larter, R. D., Graham, A. G. C., Ehrmann, W., Moreton, S. G., and Forwick, M.: Deglacial history of the West Antarctic Ice Sheet in the western Amundsen Sea Embayment, Quaternary Sci. Rev., 30, 488-505, https://doi.org/10.1016/j.quascirev.2010.11.020, 2011.

Smith, J. A., Andersen, T. J., Shortt, M., Gaffney, A. M., Truffer, M., Stanton, T. P., Bindschadler, R., Dutrieux, P., Jenkins, A., Hillenbrand, C. D., Ehrmann, W., Corr, H. F. J., Farley, N., Crowhurst, S., and Vaughan, D. G.: Sub-ice-shelf sediments record history of twentieth-century retreat of Pine Island Glacier, Nature, 541, 77-80, https://doi.org/10.1038/nature20136, 2017.

Smith, J. A., Graham, A. G. C., Post, A. L., Hillenbrand, C. D., Bart, P. J., and Powell, R. D.: The marine geological imprint of Antarctic ice shelves, Nat. Commun., 10, 5635, https://doi.org/10.1038/s41467-019-13496-5, 2019.

Spagnolo, M., Clark, C. D., Ely, J. C., Stokes, C. R., Anderson, J. B., Andreassen, K., Graham, A. G. C., and King, E. C.: Size, shape and spatial arrangement of mega-scale glacial lineations from a large and diverse dataset, Earth. Surf. Proc. Land., 39, 1432-1448, https://doi.org/10.1002/esp.3532, 2014.

Stein, R., Nam, S.-I., Grobe, H., and Hubberten, H.-W.: Late Quaternary glacial history and short-term ice-rafted debris fluctuations along the East Greenland continental margin, in: Late Quaternary Palaeoceanography of the North Atlantic Margins, vol. 111, edited by: Andrews, J. T., Austin, W. E. N., Bergsten, H., and Jennings, A. E., Geological Society of London, Special Publications, 135-151, 1996.

Stewart, F. S. and Stoker, M. S.: Problems associated with seismic facies analysis of diamicton-dominated, shelf glacigenic sequences, Geo-Mar. Lett., 10, 151-156, https://doi.org/10.1007/BF02085930, 1990.

Stokes, C. R. and Clark, C. D.: Geomorphological criteria for identifying Pleistocene ice streams, Ann. Glaciol., 28, 67-74, https://doi.org/10.3189/172756499781821625, 1999.

Straneo, F. and Heimbach, P.: North Atlantic warming and the retreat of Greenland's outlet glaciers, Nature, 504, 36-43, https://doi.org/10.1038/nature12854, 2013.

Stuiver, M., Reimer, P. J., and Reimer, R. W.: CALIB 8.2 [WWW program], available at: http://calib.org, last access: 13 October 2020.

Syring, N., Stein, R., Fahl, K., Vahlenkamp, M., Zehnich, M., Spielhagen, R. F., and Niessen, F.: Holocene changes in sea-ice cover and polynya formation along the eastern North Greenland shelf: New insights from biomarker records, Quaternary Sci. Rev., 231, 106173, https://doi.org/10.1016/j.quascirev.2020.106173, 2020.

Vorren, T. O. and Plassen, L.: Late weichselian and holocene sediment flux and sedimentation rates in Andfjord and Vågsfjord, North Norway, J. Quaternary Sci., 17, 161-180, https://doi.org/10.1002/jqs.662, 2002.

Vorren, T. O., Hald, M., Edvardsen, M., and Lind-Hansen, O. W.: Glacigenic sediments and sedimentary environments on continental shelves: general principles with a case study from the Norwegian shelf, in: Glacial deposits in north-west Europe, edited by: Ehlers, J., A A Balkema Publishers, Rotterdam, 61-73, 1983.

Vorren, T. O., Hald, M., and Lebesbye, E.: Late Cenozoic environments in the Barents Sea, Paleoceanography, 3, 601-612, 1988.

Weber, M. E., Niessen, F., Kuhn, G., and Wiedicke, M.: Calibration and application of marine sedimentary physical properties using a multi-sensor core logger, Mar. Geol., 136, 151-172, 1997.

Weidick, A., Andreasen, C., Oerter, H., and Reeh, N.: Neoglacial glacier changes around Storstrømmen, north-east Greenland, Polarforschung, 64, 95-108, 1996.

Werner, K., Müller, J., Husum, K., Spielhagen, R. F., Kandiano, E. S., and Polyak, L.: Holocene sea subsurface and surface water masses in the Fram Strait - Comparisons of temperature and sea-ice reconstructions, Quaternary Sci. Rev., 147, 194-209, https://doi.org/10.1016/j.quascirev.2015.09.007, 2016.

Wilson, N. J. and Straneo, F.: Water exchange between the continental shelf and the cavity beneath Nioghalvfjerdsbræ (79 North Glacier), Geophys. Res. Lett., 42, 7648-7654, https://doi.org/10.1002/2015GL064944, 2015.

Winkelmann, D., Jokat, W., Jensen, L., and Schenke, H. W.: Submarine end moraines on the continental shelf off NE Greenland - Implications for Lateglacial dynamics, Quaternary Sci. Rev., 29, 1069-1077, https://doi.org/10.1016/j.quascirev.2010.02.002, 2010.

Winsborrow, M. C. M., Andreassen, K., Corner, G. D., and Laberg, J. S.: Deglaciation of a marine-based ice sheet: Late Weichselian palaeo-ice dynamics and retreat in the southern Barents Sea reconstructed from onshore and offshore glacial geomorphology, Quaternary Sci. Rev., 29, 424-442, https://doi.org/10.1016/j.quascirev.2009.10.001, 2010.

Zamelczyk, K., Rasmussen, T. L., Husum, K., Haflidason, H., de Vernal, A., Ravna, E. K., Hald, M., and Hillaire-Marcel, C.: Paleoceanographic changes and calcium carbonate dissolution in the central Fram Strait during the last $20 \mathrm{ka}$, Quaternary Res., 78, 405-416, https://doi.org/10.1016/j.yqres.2012.07.006, 2012. 